\title{
An Investigation into the Stability of Graphitic C3N4 as a Photocatalyst for CO2 Reduction
}

Pomilla, F., Cortes, M. A., Hamilton, J., Molinari, R., Barbieri, G., Marci, G., Palmisano, L., Sharma, P., Brown, A., \& Byrne, J. (2018). An Investigation into the Stability of Graphitic C3N4 as a Photocatalyst for CO2 Reduction. Journal Of Physical Chemistry C, 122(50), 28727-28738. https://doi.org/10.1021/acs.jpcc.8b09237

Link to publication record in Ulster University Research Portal

\section{Published in:}

Journal Of Physical Chemistry C

\section{Publication Status:}

Published (in print/issue): 20/12/2018

DOI:

10.1021/acs.jpcc.8b09237

\section{Document Version}

Author Accepted version

\section{General rights}

Copyright for the publications made accessible via Ulster University's Research Portal is retained by the author(s) and / or other copyright owners and it is a condition of accessing these publications that users recognise and abide by the legal requirements associated with these rights.

\section{Take down policy}

The Research Portal is Ulster University's institutional repository that provides access to Ulster's research outputs. Every effort has been made to ensure that content in the Research Portal does not infringe any person's rights, or applicable UK laws. If you discover content in the Research Portal that you believe breaches copyright or violates any law, please contact pure-support@ulster.ac.uk. 


\title{
An Investigation into the Stability of Graphitic $\mathrm{C}_{3} \mathrm{~N}_{4}$ as a Photocatalyst for $\mathrm{CO}_{2}$
}

\section{Reduction}

Francesca R. Pomilla ${ }^{1,2,3}$, Maria A. L. R. M. Cortes ${ }^{4}$, Jeremy W. J. Hamilton ${ }^{4}$, Raffaele Molinari ${ }^{1}$, Giuseppe Barbieri ${ }^{3}$, Giuseppe Marci* ${ }^{2}$, Leonardo Palmisano ${ }^{2}$, Preetam K. Sharma ${ }^{4}$, Alan Brown ${ }^{4}$, John. A. Byrne ${ }^{4}$

1. Department of Environmental and Chemical Engineering, University of Calabria Via Pietro Bucci, 87036 Rende CS, Italy

2. "Schiavello-Grillone" Photocatalysis Group. Dipartimento di Energia, Ingegneria dell'informazione e modelli Matematici (DEIM), Università di Palermo Viale delle Scienze, 90128 Palermo, Italy

3 Institute on Membrane Technology (ITM-CNR), National Research Council clo University of Calabria, Cubo 17C, Via Pietro Bucci, 87036 Rende CS, Italy

4 NIBEC, Ulster University, Newtownabbey, BT37 OQB, UK

giuseppe.marci@unipa.it

\begin{abstract}
The increasing $\mathrm{CO}_{2}$ concentration in the atmosphere exerts a significant influence on global warming and climate change. The capture and utilization of $\mathrm{CO}_{2}$ by conversion to useful products is an area of active research. In this work, the photo-driven reduction of $\mathrm{CO}_{2}$ was investigated using graphitic carbon nitride $\left(\mathrm{g}-\mathrm{C}_{3} \mathrm{~N}_{4}\right)$ as a potential photocatalyst. The photocatalytic reduction of $\mathrm{CO}_{2}$ was investigated with $\mathrm{g}-\mathrm{C}_{3} \mathrm{~N}_{4}$ powder immobilized on a glass support in a batch gas phase photoreactor. The experiments were carried out under UV-Vis irradiation at $70^{\circ} \mathrm{C}$ and an initial pressure of 2.5 bar. The only gas phase product detected during the irradiation of the $g-\mathrm{C}_{3} \mathrm{~N}_{4}$ in the presence of $\mathrm{CO}_{2}$ was $\mathrm{CO}$, and the rate of production was observed to decrease over time. Oxygen
\end{abstract}


doped $\mathrm{g}-\mathrm{C}_{3} \mathrm{~N}_{4}$ was also tested for $\mathrm{CO}_{2}$ reduction but had lower efficiency that the parent $\mathrm{g}-\mathrm{C}_{3} \mathrm{~N}_{4}$. Repeated cycles of photocatalytic $\mathrm{CO}_{2}$ reduction showed a decline in the activity of the $\mathrm{g}-\mathrm{C}_{3} \mathrm{~N}_{4}$. In the absence of $\mathrm{CO}_{2}$ some $\mathrm{CO}$ generation was also observed. Characterization of used and unused materials, using FTIR and XPS, showed an increase in the oxygen functional groups following UVVis irradiation or thermal treatment. While others report the use of $\mathrm{g}-\mathrm{C}_{3} \mathrm{~N}_{4}$ as a photocatalyst, this work highlights the important need for replicates and control testing to determine material stability.

\section{Introduction}

Global warming and climate change driven mainly by rising atmospheric $\mathrm{CO}_{2}$ levels has led to political initiatives to reduce the amount of $\mathrm{CO}_{2}$ released into the atmosphere. The 2020 package is a set of binding legislation to ensure the European Union meets its climate and energy goals for the year $2020 .{ }^{1}$ The package sets three key targets: to achieve a $20 \%$ cut in greenhouse gas emissions (from 1990 levels), to generate $20 \%$ of European Union energy from renewables and a $20 \%$ improvement in energy efficiency during use. To enable progress toward the $\mathrm{CO}_{2}$ target, the European commission has established funding for storage and capture for reuse.

Artificial photosynthesis represents one potential solution to $\mathrm{CO}_{2}$ capture and utilization through the generation of fuels or platform chemicals by the reduction of $\mathrm{CO}_{2}$. Considering the energy losses in converting green energy to fuels over direct use, there is a strong economic argument for the synthesis of chemical feedstocks as compared to fuels. ${ }^{2}$ There are a range of different approaches to the utilization of solar energy for $\mathrm{CO}_{2}$ reduction. ${ }^{3,4}$ One may use an electrocatalytic system, whereby the energy to drive the electrochemical reduction of $\mathrm{CO}_{2}$ can be provided through external photovoltaic (PV) system. Also, one may use a photo-electrochemical cell (PEC) wherein a buried (PV) junction is used to drive electrochemical reduction of $\mathrm{CO}_{2}$, or indeed a PEC which utilizes a semiconductor photoelectrode which acts to both absorb the electromagnetic energy and catalyze the electrochemical 
oxidation or reduction reactions. In photocatalytic systems, the semiconductor material acts to harvest the electromagnetic energy, and both oxidation and reduction reactions take place on the surface of the same particles in close proximity. All approaches have advantages and disadvantages. ${ }^{5-9}$ In this work we are concerned with photocatalytic reduction of $\mathrm{CO}_{2}$ using graphitic carbon nitride $\left(\mathrm{g}-\mathrm{C}_{3} \mathrm{~N}_{4}\right)$. g- $\mathrm{C}_{3} \mathrm{~N}_{4}$ consists of earth-abundant $\mathrm{C}$ and $\mathrm{N}$ elements and due to its facile synthesis, non-toxicity, 2D morphology, ${ }^{10}$ appealing electronic band structure and claimed stability, ${ }^{11} \mathrm{~g}-\mathrm{C}_{3} \mathrm{~N}_{4}$ is considered to be a potential material for the solar photocatalytic reduction of $\mathrm{CO}_{2} \cdot{ }^{12}$ As reported in literature, in theory the conduction band edge of $\mathrm{g}-\mathrm{C}_{3} \mathrm{~N}_{4}$ phase is sufficiently negative to reduce $\mathrm{CO}_{2},{ }^{11,13,14}$ and the valence band edge is positive enough to split water. $\mathrm{g}-\mathrm{C}_{3} \mathrm{~N}_{4}$ has a valence band (VB) potential of +1.4 and a $\mathrm{CB}$ potential of $-1.3 \mathrm{eV}$ (vs NHE) ${ }^{14}, 15 \mathrm{~g}-\mathrm{C}_{3} \mathrm{~N}_{4}$ materials, are naturally rich in $\mathrm{N}$ basic sites, which favor weak $\mathrm{CO}_{2}$ adsorption, compared to oxide surfaces. The photocatalytic reduction of $\mathrm{CO}_{2}$ on $\mathrm{C}_{3} \mathrm{~N}_{4}$ under UV-Vis irradiation has been reported by a number of researchers utilizing heterogeneous batch reactors. When $\mathrm{g}_{-} \mathrm{C}_{3} \mathrm{~N}_{4}$ was used as a photocatalyst for $\mathrm{CO}_{2}$ reduction, $\mathrm{MeOH}$, EtOH and $\mathrm{HCOOH}$ were reported as the main products in the liquid phase, whilst $\mathrm{CH}_{4}$ and $\mathrm{CO}$ were reported to be found in the gas phase. ${ }^{16-20}$ In both liquid and gas phase photocatalytic systems, the reaction rates are very low and are reported in $\mu$ mol $\mathrm{g}^{-1} \mathrm{~h}^{-1}$. A moderate increase of $\mathrm{CO}_{2}$ photoconversion for metal $\mathrm{g}-\mathrm{C}_{3} \mathrm{~N}_{4}$ composites has been reported. In order to perform the $\mathrm{CO}_{2}$ conversion protons for these reactions are obtained from water splitting reactions, to reduce back reaction reduction and oxidation sites are often physically separated by using surface co-catalysts ${ }^{21-}$ ${ }^{23}$. The co-catalysts studied have been noble metals ${ }^{24-27}(\mathrm{Pd}, \mathrm{Pt}, \mathrm{Co}, \mathrm{Ru})$, semiconductors ${ }^{28-30}\left(\mathrm{TiO}_{2}\right.$, $\left.\mathrm{WO}_{3}, \mathrm{CeO}_{2}\right)$ and non-metal dopants $(\mathrm{O}, \mathrm{P}, \mathrm{S}) .{ }^{31-33} \mathrm{In}$ this work we investigate $\mathrm{g}-\mathrm{C}_{3} \mathrm{~N}_{4}$ and oxygen doped $\mathrm{g}-\mathrm{C}_{3} \mathrm{~N}_{4}$ as potential photocatalysts for $\mathrm{CO}_{2}$ reduction.

Polymeric carbon nitride, $\mathrm{g}-\mathrm{C}_{3} \mathrm{~N}_{4}$, exists in seven different polymorphic phases, and all of them are semiconductors. ${ }^{21,22}$ Nevertheless only g-h-heptazine and g-h-triazine phases have suitable band gaps and band edge potentials to drive photocatalytic processes. By considering the position of the VB, only the g-h-heptazine meets the potential requirements for water oxidation. ${ }^{34,35}$ As this is the only 
phase with suitable band edges to drive water oxidation, this phase of $\mathrm{g}-\mathrm{C}_{3} \mathrm{~N}_{4}$ material is the most frequently investigated as a photocatalyst. In order to increase the $\mathrm{CO}_{2}$ photoreduction activity of g$\mathrm{C}_{3} \mathrm{~N}_{4}$, many research groups have looked at doping with non-metal species to change the band structure or adsorption properties. The most frequent strategy is to dope with $\mathrm{N}$ by using hydrazine pre-treated, melamine precursor. Other dopants can be $\mathrm{S}$ and $\mathrm{O}$ deriving from thiourea and urea, respectively. Oxygen can be also provided by oxidizing the material with $\mathrm{H}_{2} \mathrm{O}_{2} \cdot{ }^{36}$ The doping has been reported to generate a second semiconductor and/or a heterojunction, which is believed to decrease the recombination of the electron-hole pairs, thereby increasing the activity. ${ }^{32,36}$ Non-metal dopants result in an increase of the VB width, in combination with an elevated CB minimum and a slightly reduced absorbance. Oxygen doping in the $\mathrm{g}-\mathrm{C}_{3} \mathrm{~N}_{4}$ lattice was reported to induce intrinsic electronic and band structure modulation, leading to improved surface area, extended visible light response, and enhanced separation efficiency of the photo-generated charge carriers. ${ }^{36}$ Oxygen doped materials have been reported as promising photocatalysts for $\mathrm{CO}_{2}$ reduction. ${ }^{32}$

Although significant works on pure and modified $\mathrm{C}_{3} \mathrm{~N}_{4}$ as an efficient potential photocatalyst for $\mathrm{CO}_{2}$ reduction have been reported, replicate testing for material stability and controls in the absence of $\mathrm{CO}_{2}$ are often not reported, ${ }^{31,37,38}$ while some report that the material maintains a percentage of stability after a number of runs. ${ }^{39}$ When the $\mathrm{g}-\mathrm{C}_{3} \mathrm{~N}_{4}$ stability is tested, the methodology relies on observing changes in product yield with time, wherein the activity is reported to be constant with reuse. ${ }^{29,} 32,40$ In a recent work, Xiao et al. ${ }^{41}$ which studied the $\mathrm{g}-\mathrm{C}_{3} \mathrm{~N}_{4}$ stability in the presence of water pollutants, found an accumulation of carbon species (by total organic carbon analysis) and $\mathrm{NO}_{3}{ }^{-}$ions in water under photocatalytic reactions (sunlight $/ \mathrm{O}_{2} /$ nanostructured $\mathrm{C}_{3} \mathrm{~N}_{4}$ conditions), suggesting chemical instability of $\mathrm{g}-\mathrm{C}_{3} \mathrm{~N}_{4}$ in the aqueous phase. In this study, we describe changes in activity and photocatalyst chemistry during the photocatalytic reduction of $\mathrm{CO}_{2}$ in the gas phase with water as the reductant and with $\mathrm{g}-\mathrm{C}_{3} \mathrm{~N}_{4}$ and an oxygen doped analogue catalyst as a function of time and reuse cycle. In addition, the source of observed $\mathrm{CO}$ produced during photoreduction testing was performed using control runs (studying the potential photocatalysts activity in $\mathrm{CO}_{2}$ absence). In order to correlate 
changes in photocatalytic activity with reactor history, the $\mathrm{g}-\mathrm{C}_{3} \mathrm{~N}_{4}$ chemical structure was investigated by FTIR and X-ray photoelectron spectroscopy (XPS) analyses both before and after its use in the photocatalytic reactor.

\section{Experimental section}

\subsection{Synthesis of $\mathrm{g}-\mathrm{C}_{3} \mathrm{~N}_{4}$ and oxygen chemically modified $\mathrm{g}-\mathrm{C}_{3} \mathrm{~N}_{4}$ powder.}

g- $\mathrm{C}_{3} \mathrm{~N}_{4}$ was prepared by a two-stage thermal polymerization process. ${ }^{42}$ Firstly, melamine (10 g) was directly heated at $520^{\circ} \mathrm{C}$, in a crucible with a cover, for $2 \mathrm{~h}$ in static air with a temperature ramp rate of $2^{\circ} \mathrm{C} / \mathrm{min}$. The resultant solid was ground with a pestle and mortar, then spread on the bottom of a ceramic bowl with a diameter of $14 \mathrm{~cm}$, and then heat treated in air at $500{ }^{\circ} \mathrm{C}$ for $4 \mathrm{~h}$ with a temperature ramp rate of $3^{\circ} \mathrm{C} / \mathrm{min}$. The resulting yellow powder was designated g- $\mathrm{C}_{3} \mathrm{~N}_{4}$.

Oxygen doped g- $\mathrm{C}_{3} \mathrm{~N}_{4}$, was prepared by treat the graphitic material with $\mathrm{H}_{2} \mathrm{O}_{2}{ }^{43}$ Briefly, $1 \mathrm{~g}$ of g$\mathrm{C}_{3} \mathrm{~N}_{4}$ (as synthesized previously) was dispersed in $80 \mathrm{~mL}$ of $30 \% \mathrm{H}_{2} \mathrm{O}_{2}$ solution and placed in a Teflon vessel of $100 \mathrm{~mL}$. The vessel was then heated up to $130{ }^{\circ} \mathrm{C}$ and kept at this temperature for $24 \mathrm{~h}$ in an autoclave. After cooling, the dispersion was filtered, and the powder was washed with hot water to remove the $\mathrm{H}_{2} \mathrm{O}_{2}$. Once no $\mathrm{H}_{2} \mathrm{O}_{2}$ was detected in the washings (by $\mathrm{KMnO}_{4}$ method), the powder was dried at $60^{\circ} \mathrm{C}$ and designated $\mathrm{O}_{\mathrm{R}}-\mathrm{C}_{3} \mathrm{~N}_{4}$. Oxygen doped $\mathrm{g}-\mathrm{C}_{3} \mathrm{~N}_{4}$ was also produced by thermal treatment of pure $\mathrm{g}-\mathrm{C}_{3} \mathrm{~N}_{4}$ thin films designated $\mathrm{O}_{\mathrm{T}}-\mathrm{C}_{3} \mathrm{~N}_{4}$ as described below in photocatalyst immobilization.

\section{2 g- $\mathrm{C}_{3} \mathrm{~N}_{4}$ and oxygen thermally modified g- $\mathrm{C}_{3} \mathrm{~N}_{4}$ immobilization.}

To test the materials $\left(\mathrm{g}-\mathrm{C}_{3} \mathrm{~N}_{4}\right.$ and $\left.\mathrm{O}_{\mathrm{R}}-\mathrm{C}_{3} \mathrm{~N}_{4}\right)$ for $\mathrm{CO}_{2}$ photoreduction activity, $8 \mathrm{mg}$ of powder was immobilized on borosilicate glass $\left(3 \times 2.5 \mathrm{~cm}^{2}\right)$ by spray coating using a water dispersion of $25 \mathrm{~g} \mathrm{~L}^{-1}$ 
of $\mathrm{C}_{3} \mathrm{~N}_{4}$. Following spray coating, the samples were dried at $70{ }^{\circ} \mathrm{C}$. The $\mathrm{g}-\mathrm{C}_{3} \mathrm{~N}_{4}$ sample was used without further treatment or annealed at $450{ }^{\circ} \mathrm{C}\left(2 \mathrm{~h}\right.$ with ramp up and down rate $\left.2^{\circ} \mathrm{C} \min ^{-1}\right)$ to produce $\mathrm{O}_{T}-\mathrm{C}_{3} \mathrm{~N}_{4}$ prior to testing for $\mathrm{CO}_{2}$ reduction activity.

\subsection{Photocatalytic reduction of $\mathrm{CO}_{2}$}

Photocatalytic tests were performed in a stainless steel reactor, with an internal volume of $120 \mathrm{~mL}$. The reactor was fitted with a quartz window to allow irradiation of the catalyst. The reactor set up is shown in Figure 1 and is similar to that reported by Cortes et al. ${ }^{44}$. The catalyst samples were placed inside the reactor facing the quartz window. High purity water $(1 \mathrm{~mL})$ was added to the bottom of the reactor at the start of each experiment. The reactor was purged for 10 min with $20 \% \mathrm{CO}_{2}(\mathrm{BOC}$, UN1013, 99.99\% purity) in $\operatorname{Ar}$ (BOC, UN1006, 99.998\% purity) before sealing at a pressure of 2 bar. For the control tests in the absence of $\mathrm{CO}_{2}$, the reactor was instead purged for 10 min with Ar, and 1 $\mathrm{mL}$ of heated water was added to the reactor. The temperature of the reactor was maintained with thermal tape at $70^{\circ} \mathrm{C}$ for all tests. The light source was a $100 \mathrm{~W}$ Xe lamp (LOT Oriel) with an IR filter (light intensity reported in the support information section, see Figure S1).

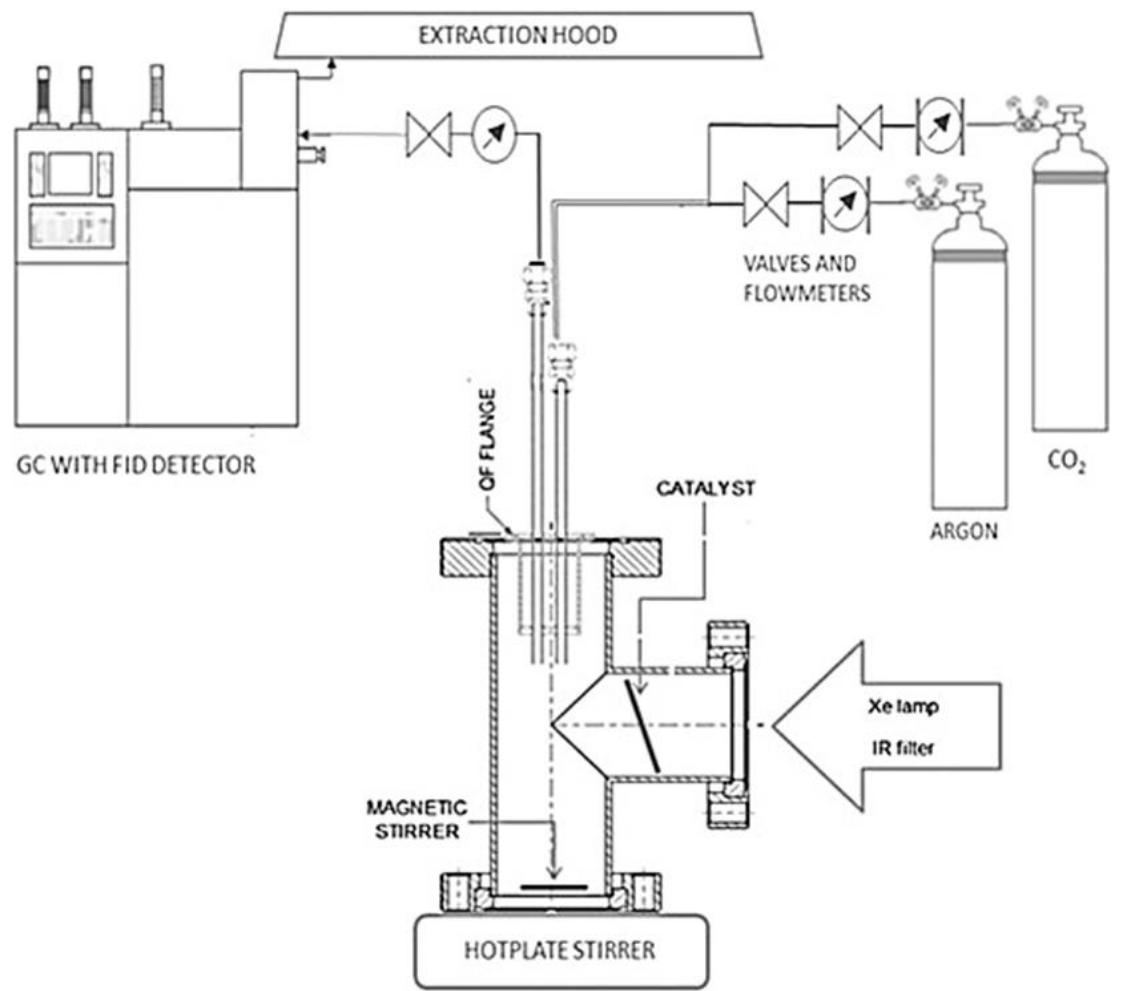


Figure 1. Batch photoreactor scheme equipped with a mass flow controller and light source. The system is on line connected with a GC-FID/TCD. ${ }^{44}$

The gaseous products obtained following periodic irradiation were analyzed by gas chromatography (GC) with a flame ionization detector (FID) and using Helium (BOC, UN1046, 99.999\% purity) as a carrier gas. The GC (Agilent Technologies 7890B) was connected directly to the reactor and samples were analyzed every 30 min leading to a decrease in pressure inside the reactor $(0.20$ bar $)$ each time a measurement was performed. Tests were replicated to determine the reusability of the material and were named $\mathrm{RnCO}_{2}$ (where $\mathrm{R}$ means the replicate runs and $\mathrm{n}$ is the number cycles of $\mathrm{CO}_{2}$ reduction testing performed). The control test in the absence of $\mathrm{CO}_{2}$ was carried out with the same sampling time points as the other tests and was designated as RnAr. To investigate the effect of surface contaminants some of the samples were exposed to photocatalytic cleaning in the presence of oxygen prior to testing under standard $\mathrm{CO}_{2}$ reduction conditions.

\subsection{Materials characterization}

A Perkin Elmer Varian 640-IR FTIR was used for FTIR characterization of the samples before and after use. Analysis was performed with a resolution of $10 \mathrm{~cm}^{-1}$ step size, compiled from 50 scans and measured in triplicate. The crystalline phase structures were analyzed at room temperature by powder X-ray diffraction by using a Panalytical Empyrean, equipped with $\mathrm{Cu} \mathrm{K}_{\alpha}$ radiation $(1.5406 \AA)$ and PixCel-1D (tm) detector. Diffuse reflectance was used to determine the optical characteristics of the materials and measured with a Shimadzu UV-2401 PC spectrophotometer, with $\mathrm{BaSO}_{4}$ as the reference material. A Kratos Axis Ultra system using a monochromatic Al K $\mathrm{X}_{\alpha}$-ray source (hv 1486 eV) was used to measure X-ray photoelectron spectra (XPS) from used and unused material plates. Triplicate analysis was performed, sampling from different areas of the material plates. For all the elements, the coefficient of variance was less than $10 \%$. The binding energy at $284.8 \mathrm{eV}$ was used for calibration of $\mathrm{C} 1 \mathrm{~s}$ chemical shifts. Survey scans covering the entire energy range were performed with $160 \mathrm{eV}$ energy window, whilst high resolution scans of specific elemental regions were 
performed at a reduced $20 \mathrm{eV}$. The data were fitted using a mixed Gaussian-Lorentzian (GL30) function on a Shirley background.

\section{Results and Discussion}

\subsection{Characterization materials}

Analysis of the $\mathrm{g}-\mathrm{C}_{3} \mathrm{~N}_{4}$ and $\mathrm{O}_{\mathrm{R}}-\mathrm{C}_{3} \mathrm{~N}_{4}$ powder was undertaken using, FTIR, XRD, and UV-Vis reflectance. The FTIR analysis correlates to previous reports on $g-\mathrm{C}_{3} \mathrm{~N}_{4} \cdot{ }^{32,45-52}$ The finger printing from 807 to $1650 \mathrm{~cm}^{-1}$ and from 3100 to $3500 \mathrm{~cm}^{-1}$ by FTIR analysis demonstrates that the materials synthesized are $\mathrm{C}_{3} \mathrm{~N}_{4}$ structure type (Figure 2). The peaks at $807 \mathrm{~cm}^{-1}$ are the characteristic breathing mode of the s-triazine ring system. The peaks at c.a. $1242,1322,1412,1563$, and $1634 \mathrm{~cm}^{-1}$ are typical stretching vibration modes of $\mathrm{C}=\mathrm{N}$ and $\mathrm{C}-\mathrm{N}$ heterocycles. In addition, the broad peak between 3600 and $3000 \mathrm{~cm}^{-1}$ is caused by the $\mathrm{NH}$ and $\mathrm{OH}$ stretches. However $\mathrm{C}-\mathrm{O}$ and $\mathrm{C}=\mathrm{O}$ bonds are difficult to distinguish in $\mathrm{O}$ doped $\mathrm{g}-\mathrm{C}_{3} \mathrm{~N}_{4}$ by FT-IR, as the $\mathrm{C}-\mathrm{N}, \mathrm{C}-\mathrm{C}$ and $\mathrm{C}-\mathrm{O}$ bonds have very similar force constants. ${ }^{53}$ Due to this constraint and the limited amount of $\mathrm{O}$ expected to be incorporated in the $\mathrm{O}_{\mathrm{R}^{-}}$ $\mathrm{C}_{3} \mathrm{~N}_{4}$, no appreciable changes were observed when comparing it with the $\mathrm{g}-\mathrm{C}_{3} \mathrm{~N}_{4}$ catalyst by FTIR. 


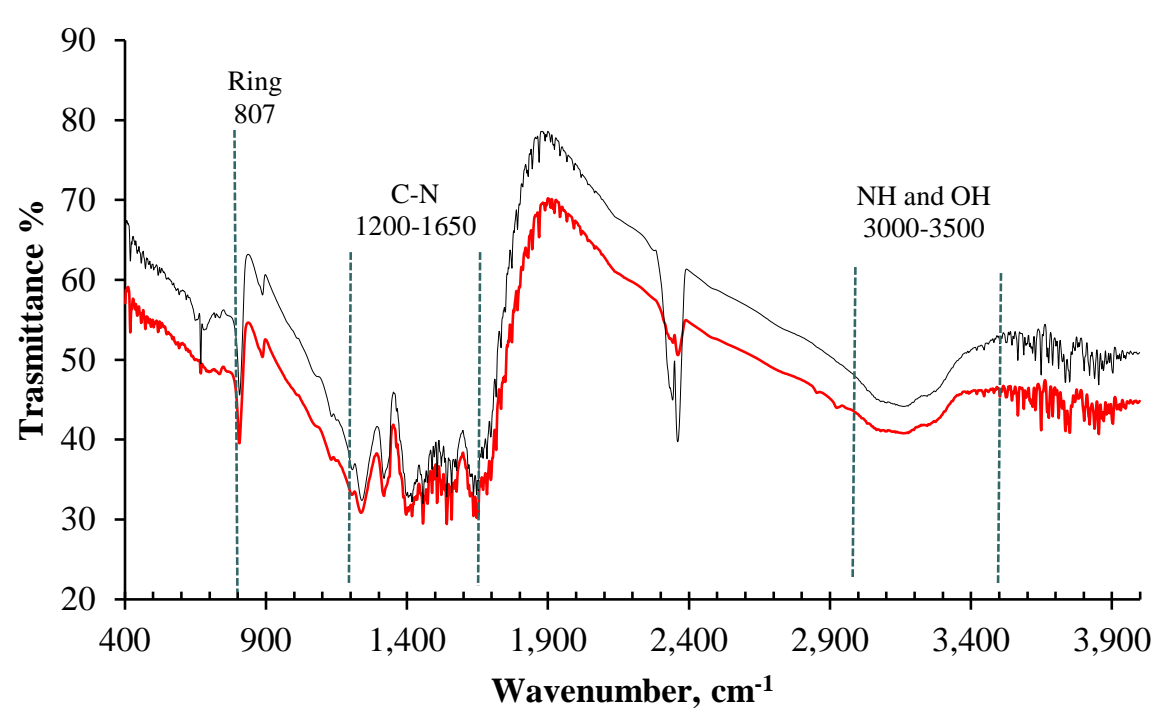

Figure 2. FTIR spectra of as synthesized $\mathrm{g}-\mathrm{C}_{3} \mathrm{~N}_{4}$ (red line) and $\mathrm{O}_{\mathrm{R}}-\mathrm{C}_{3} \mathrm{~N}_{4}$ (black line) showing characteristic $\mathrm{g}-\mathrm{C}_{3} \mathrm{~N}_{4}$ fingerprint.

XRD analysis of the synthesized material showed a main $2 \theta$ peak at $27.4^{\circ}$ which has been assigned to the (002) plane of $\mathrm{g}-\mathrm{C}_{3} \mathrm{~N}_{4}{ }^{14,54}$ This corresponds to a d-spacing of $0.326 \mathrm{~nm}$. This peak is usually assigned to the distance between the layers of the 2D graphitic material, which undergo a little leftshift in the $\mathrm{O}$ doped materials, as reported in literature. ${ }^{43}$ The secondary intensive peak at $2 \theta$ of $13.0^{\circ}$ is attributed to the (100) plane, with a d-spacing of $0.680 \mathrm{~nm}$, which is usually reported as the intralayer d-spacing. ${ }^{14,54}$ From identification of these features in the synthesized $\mathrm{g}-\mathrm{C}_{3} \mathrm{~N}_{4}$ material and comparison to tri-s-triazine spectra from literature, the synthesized materials can be confirmed to be the h-g heptazine phase of $\mathrm{C}_{3} \mathrm{~N}_{4}$. The XRD spectra of the synthesized materials compared to expected peak positions previously reported by Fina et al ${ }^{54}$ are shown in Figure 3. 


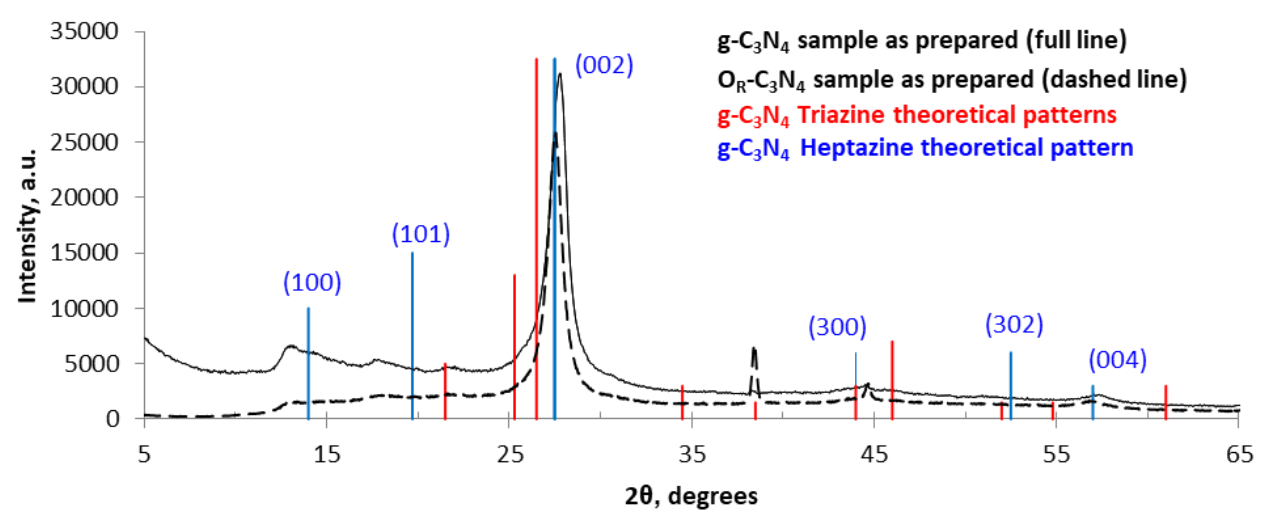

Figure $3 \mathrm{XRD}$ patterns of pure $\mathrm{g}-\mathrm{C}_{3} \mathrm{~N}_{4}$ and $\mathrm{O}_{\mathrm{R}}-\mathrm{C}_{3} \mathrm{~N}_{4}$ as prepared and the peak positions for two phases of $\mathrm{g}-\mathrm{C}_{3} \mathrm{~N}_{4}$ reported by Fina et al. ${ }^{35,54}$ The name reported heptazine (tri-s-triazine) represents the melem unit.

To discriminate between the different phases of $\mathrm{g}-\mathrm{C}_{3} \mathrm{~N}_{4}$ and to estimate the band gap energy of the material, the optical band gap was measured. When a semiconductor absorbs light with suitable wavelength, electrons are excited from $\mathrm{VB}$ to $\mathrm{CB}$ with the simultaneous formation of holes in the VB. These charges produced by photoexcitation can reduce and oxidize the adsorbed surface species, respectively, or give rise to recombination phenomena. A recent study reports a computational method which allows to correlate the thickness of s-triazine and h-g heptazine $\mathrm{C}_{3} \mathrm{~N}_{4}$ with the band gap energy of the materials. ${ }^{55}$ Diffuse reflectance spectroscopy was utilized to determine the band gap of both synthesized $\mathrm{g}-\mathrm{C}_{3} \mathrm{~N}_{4}$ catalysts (Figure 4). For pure $\mathrm{g}-\mathrm{C}_{3} \mathrm{~N}_{4}$ the optical band gap was 2.8 $\mathrm{eV}$ and for the $\mathrm{O}_{\mathrm{R}}-\mathrm{C}_{3} \mathrm{~N}_{4}$ the optical band gap was determined to be $2.7 \mathrm{eV}$. Both values appear consistent with a hexagonally structured h-g-heptazine $\mathrm{C}_{3} \mathrm{~N}_{4}{ }^{35}$ The samples doped with oxygen showed a red shift of the optical band gap with respect to the pristine materials. ${ }^{14,32,46}$ 


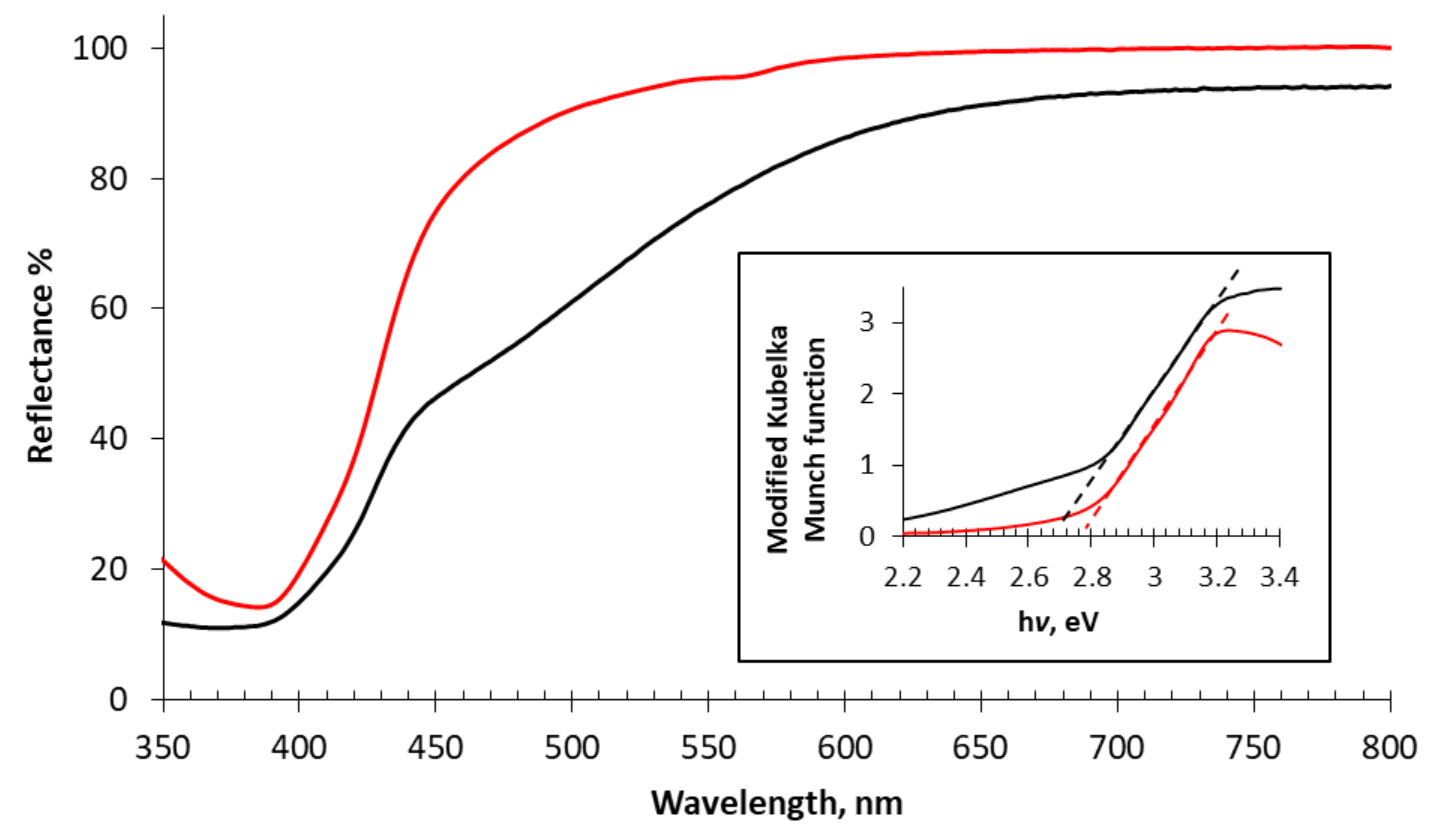

Figure 4. UV-Vis diffuse reflectance spectra of powder of pure $\mathrm{g}-\mathrm{C}_{3} \mathrm{~N}_{4}$ (red line) and $\mathrm{O}_{\mathrm{R}}-\mathrm{C}_{3} \mathrm{~N}_{4}$ (black line) as prepared samples. The inset shows the $\mathrm{C}_{3} \mathrm{~N}_{4}$ Kubelka-Munk function $v$ s photon energy, giving the graphic interpolation a band gap energy value equal to 2.8 .

\subsection{Photocatalytic reduction of $\mathrm{CO}_{2}$}

Measurement of photocatalytic activity for $\mathrm{CO}_{2}$ reduction was performed in a gas phase batch photoreactor testing the $\mathrm{g}-\mathrm{C}_{3} \mathrm{~N}_{4}, \mathrm{O}_{\mathrm{R}}-\mathrm{C}_{3} \mathrm{~N}_{4}$ and $\mathrm{O}_{\mathrm{T}}-\mathrm{C}_{3} \mathrm{~N}_{4}$ immobilized samples. Chromatographic determination of products from photocatalytic testing yielded only $\mathrm{CO}$, within the limits of detection. $\mathrm{No}_{2}, \mathrm{O}_{2}$ (from water splitting reactions), methane or other hydrocarbons were observed. A typical graph of $\mathrm{CO}$ production vs time using immobilized $\mathrm{g}-\mathrm{C}_{3} \mathrm{~N}_{4}$ is shown in Figure 5. 


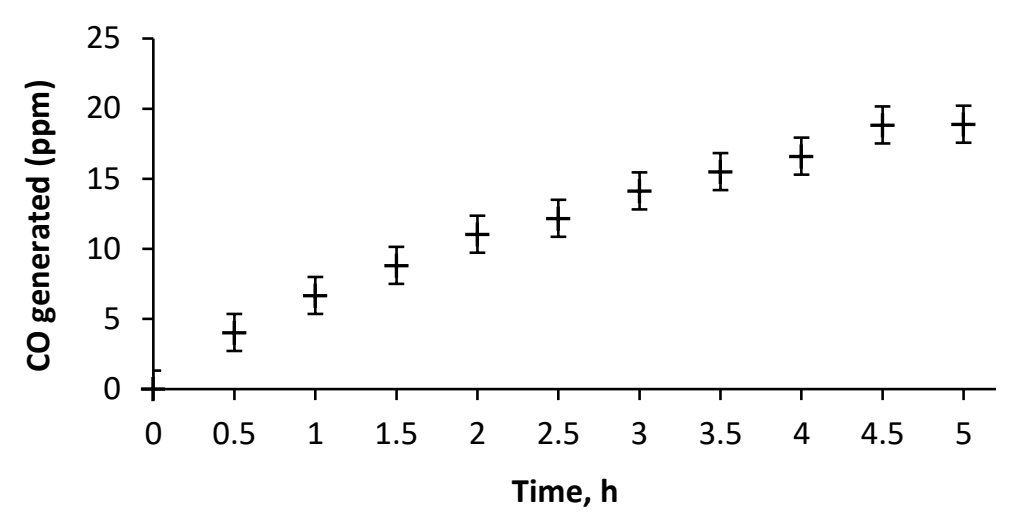

Figure 5. Concentration of $\mathrm{CO}$ measured at different time points over $5 \mathrm{~h}$ irradiation in the presence of $\mathrm{CO}_{2}$ using $\mathrm{g}-\mathrm{C}_{3} \mathrm{~N}_{4}$.

The samples were retested to investigate their stability. The subsequent reuse of samples showed a decline in the $\mathrm{CO}$ concentration (Figure 6) with replicates $\left(\mathrm{R} 1 \mathrm{CO}_{2}\right.$ and $\left.\mathrm{R} 2 \mathrm{CO}_{2}\right)$.

Control runs in the absence of $\mathrm{CO}_{2}$ were undertaken. In the absence of $\mathrm{CO}_{2}, \mathrm{CO}$ was still observed as a product, and a similar trend of lower CO generation on reuse was detected (Figure 6-R1-R3Ar runs). The observation of only $\mathrm{CO}$ as gaseous product, the declining $\mathrm{CO}$ generation rate (on reuse or extended use), and the observation of $\mathrm{CO}$ in the absence of $\mathrm{CO}_{2}$ suggest that some $\mathrm{CO}_{2}$ molecules from atmosphere remain strongly adsorbed on catalyst surface. To confirm this behavior a batch test was carried out in inert atmosphere in absence of $\mathrm{CO}_{2}\left(\mathrm{~N}_{2}\right.$ humid $)$ at atmospheric pressure and under visible light. This test confirmed a release of $\mathrm{CO}_{2}$ with the irradiation time as reported in Figure $\mathrm{S} 2$. Consequently, the adsorbed $\mathrm{CO}_{2}$ could be responsible for the observed $\mathrm{CO}$. In fact, in presence of lower $\mathrm{CO}_{2}$ amounts (just the adsorbed one), a slower catalyst inactivation occurred (see Figure 6) with respect to the test in presence of higher $\mathrm{CO}_{2}$ concentration (20\% in Ar flow). The $\mathrm{CO}$ yield was slightly higher for repeat experiments undertaken in the absence of $\mathrm{CO}_{2}$ (Figure 6). DFT studies by Wu et al suggest physisorption of $\mathrm{CO}_{2}$ and $\mathrm{CO}$ leads to a buckling of the carbon nitride requiring energy input for desorption and a straightening of the underlying carbon nitride. ${ }^{56}$ The desorption of $\mathrm{CO}$ in $\mathrm{CO}_{2}$ compared to an argon atmosphere (absence of $\mathrm{CO}_{2}$ ) would be limited by interactions with surface adsorbates maintaining a crumpled structure that reduces the desorption. 


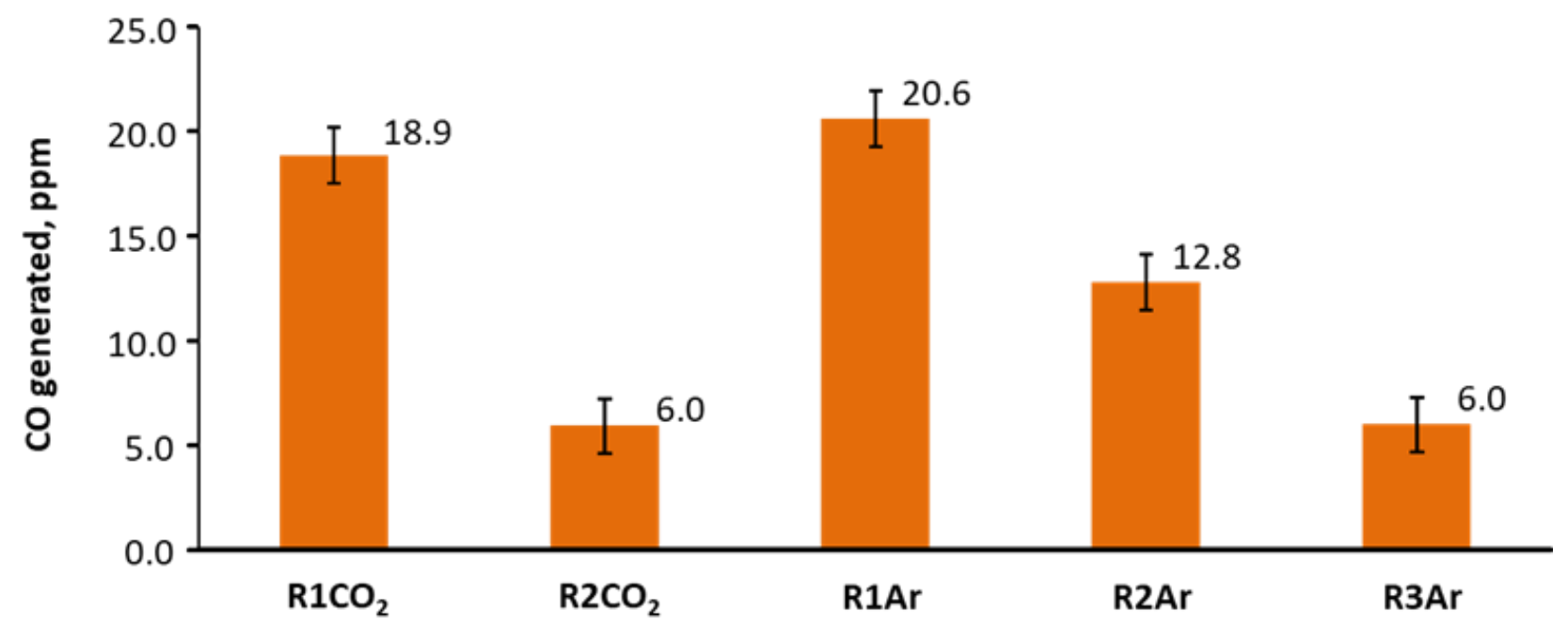

Figure 6. $\mathrm{CO}$ concentration obtained after $5 \mathrm{~h}$ of irradiation time in the presence $\left(\mathrm{RnCO}_{2}\right)$ and in the absence (RnAr) of $\mathrm{CO}_{2}$ with $\mathrm{g}-\mathrm{C}_{3} \mathrm{~N}_{4}$.

To investigate if adsorbed $\mathrm{CO}_{2}$ or organic fouling was an issue, a twice used $\left(\mathrm{R}_{2} \mathrm{CO}_{2}\right)$ sample was photocatalytically cleaned for $3 \mathrm{~h}$ in $\mathrm{O}_{2}$ flow under UV-Vis irradiation. The photocatalytic cleaning with $\mathrm{O}_{2}$ did not alter the material reactivity within the errors of the analytical system as shown in Figure 7.

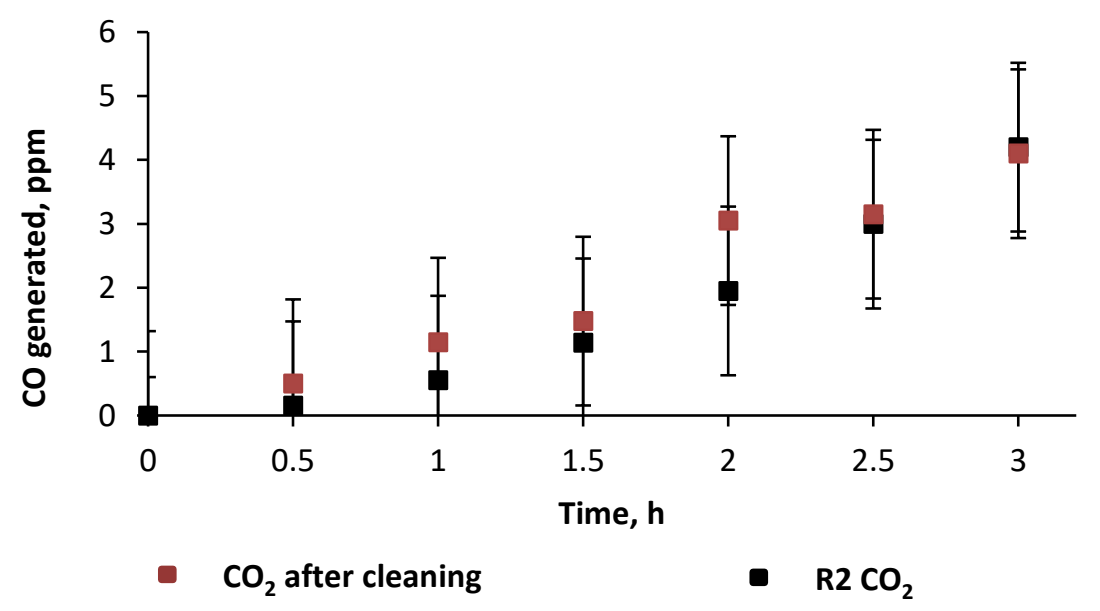

Figure 7. $\mathrm{CO}$ photo-generated in the presence of $\mathrm{CO}_{2}$, before $\left(\mathrm{R}_{2} \mathrm{CO}_{2}\right)$ and after cleaning $\left(\mathrm{CO}_{2}\right.$ after cleaning) obtained during $3 \mathrm{~h}$ of irradiation with $\mathrm{g}-\mathrm{C}_{3} \mathrm{~N}_{4}$ as potential photocatalyst. 
An oxygen thermally doped carbon nitride, $\mathrm{O}_{\mathrm{T}}-\mathrm{C}_{3} \mathrm{~N}_{4}$, was also tested for $\mathrm{CO}_{2}$ reduction using the same methodology as the one utilized in $\mathrm{g}-\mathrm{C}_{3} \mathrm{~N}_{4}$ testing. During this experiment, only $\mathrm{CO}$ was detected, the CO generated was observed to decrease with reuse. This is a similar trend to that observed in the case of pure $\mathrm{g}-\mathrm{C}_{3} \mathrm{~N}_{4}$. Comparison of activity observed with pure $\mathrm{g}-\mathrm{C}_{3} \mathrm{~N}_{4}$ and $\mathrm{O}_{\mathrm{T}}-\mathrm{C}_{3} \mathrm{~N}_{4}$ showed oxygen modification to be detrimental to $\mathrm{CO}$ formation (Figure 8). Carbon nitride chemically oxygen doped material, $\mathrm{O}_{\mathrm{R}}-\mathrm{C}_{3} \mathrm{~N}_{4}$, was also tested under identical experimental conditions and the yield of $\mathrm{CO}$ detected was smaller than those found for the thermal oxygen doped and unmodified $\mathrm{C}_{3} \mathrm{~N}_{4}$ samples.

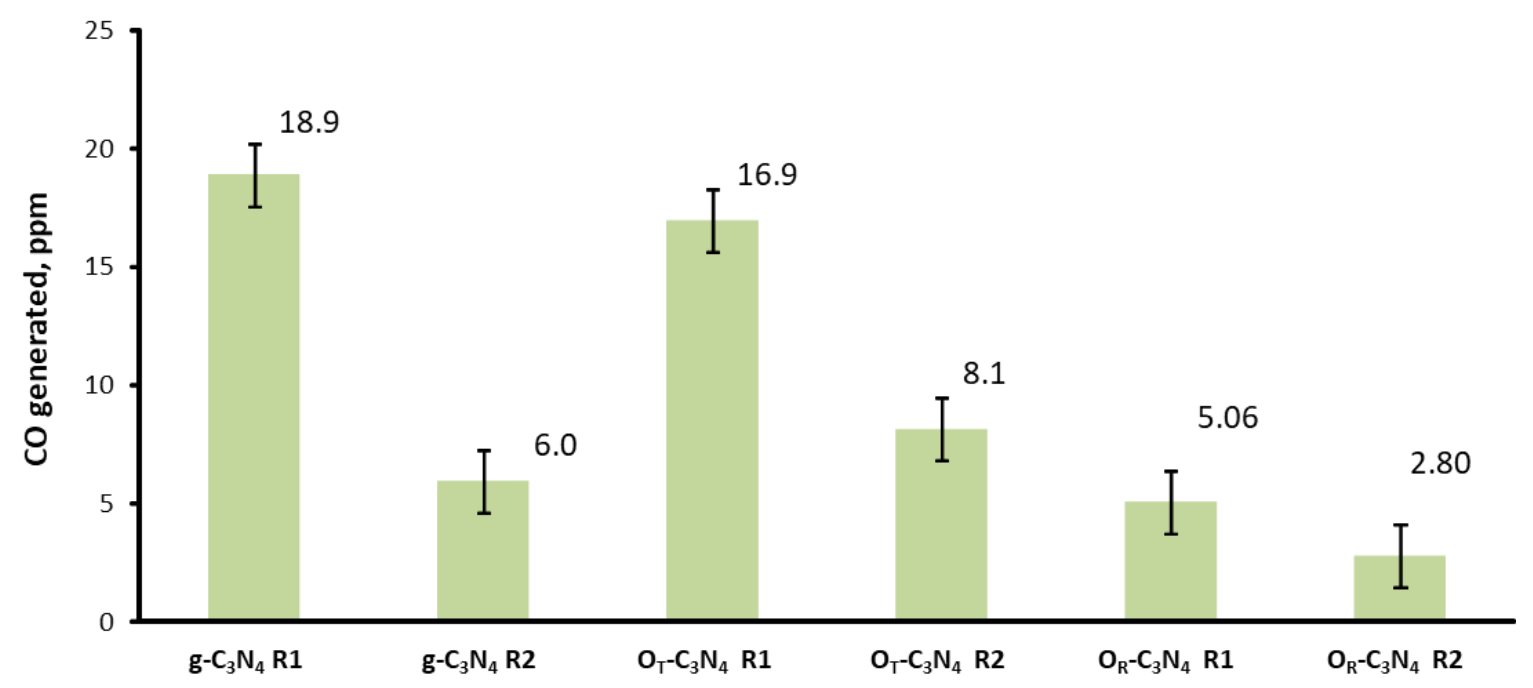

Figure 8. Reproducibly test of $\mathrm{CO}$ production in the presence of $\mathrm{g}-\mathrm{C}_{3} \mathrm{~N}_{4}$ and $\mathrm{O}_{\mathrm{T}}-\mathrm{C}_{3} \mathrm{~N}_{4}$ after $5 \mathrm{~h}$ of irradiation time in the presence of $\mathrm{CO}_{2}$.

Table S1 reports the amount of phototogenerated CO expressed in terms of both, ppm and $\mu \mathrm{mol} \mathrm{\textrm {g } ^ { - }}$ ${ }^{1}$ catalyst. The apparent Quantum Yield, calculated according to Tan et al., ${ }^{57}$ is also reported. Notably, the yields decrease with reuse for all catalysts tested.

Given the limited range of products detected under irradiation, the reduction in product yield with extended use, and the decrease in activity for the $\mathrm{O}_{\mathrm{R}}-\mathrm{C}_{3} \mathrm{~N}_{4}$ as compared to the $\mathrm{O}_{\mathrm{T}}-\mathrm{C}_{3} \mathrm{~N} 4$ and unmodified samples, oxidation of $\mathrm{g}-\mathrm{C}_{3} \mathrm{~N}_{4}$ was considered as an alternative source of $\mathrm{CO}$ observed. 
Therefore, samples were analyzed before and after use by XPS and FTIR to determine the degree of oxidation consistent with this hypothesis.

The structural and functional groups reported for $\mathrm{g}-\mathrm{C}_{3} \mathrm{~N}_{4}$ are given in Table 1. FTIR analysis was used to determine if any changes to the functional groups following use as a photocatalyst (Figure 9). All samples showed the finger printing region characteristic for heptazine subunit and functional groups consistent with expected positions for $\mathrm{g}-\mathrm{C}_{3} \mathrm{~N}_{4}$ as detailed in Table 1 .

Table 1. Peak positions of structural and functional groups observed by FTIR spectra for $\mathrm{g}-\mathrm{C}_{3} \mathrm{~N}_{4}$ and $\mathrm{O}-\mathrm{C}_{3} \mathrm{~N}_{4}$ samples.

\begin{tabular}{|c|c|c|}
\hline \multicolumn{2}{|c|}{ FTIR analysis } & \multirow{2}{*}{ Reference } \\
\cline { 1 - 2 } $\begin{array}{c}\text { Wavenumber, } \\
\mathbf{c m}^{-1}\end{array}$ & Functional group & \\
\hline $\begin{array}{c}1250-1324-1405- \\
1454-1571-1636\end{array}$ & $\mathrm{C}_{6} \mathrm{~N}_{7}$ heptazine heterocycle ring & $32,45-52$ \\
\hline $807-813$ & triazine ring stretching & $32,45-52$ \\
\hline 892 & Cross link heptazine deformation & 45 \\
\hline 1654 & N-H deformation & 46,50 \\
\hline 1610 & C=N & $47,51,52$ \\
\hline $3469-3420$ & NH 2 stretching. & $46,47,50,52$ \\
\hline $3337-3137$ & asymmetric and symmetric stretching N-H & $32-47,51,52$ \\
\hline $3500-3100,3350$ & OH & $32,58,59$ \\
\hline
\end{tabular}

A decrease in the absorbance associated with the $\mathrm{g}-\mathrm{C}_{3} \mathrm{~N}_{4}$ functional groups was observed following use in the photoreactor (see Figure 9). Such changes were also analyzed by XPS. 


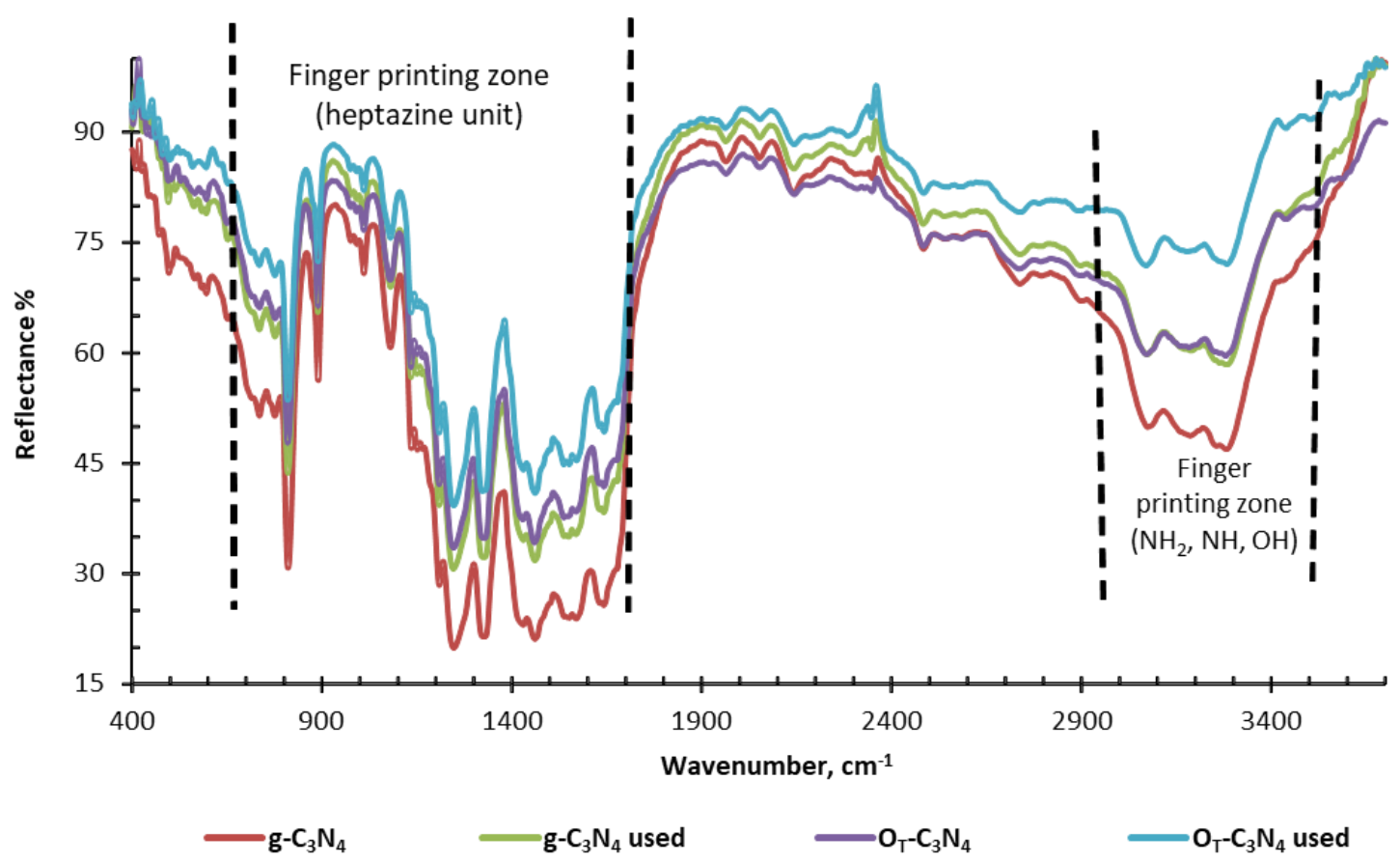

Figure 9. Diffuse FTIR analyses for each sample used and unused.

The XPS elemental profiles and expected position of peaks related to structural and functional groups have previously been reported by researchers investigating $\mathrm{g}-\mathrm{C}_{3} \mathrm{~N}_{4}$, as detailed in Table 2 . Using this information, in conjunction with analysis of samples before and after photocatalytic treatment, changes to the photocatalyst surface during $\mathrm{CO}_{2}$ reduction are reported.

Table 2. Structural and functional group reported peak positions observed in XPS for $\mathrm{g}_{-} \mathrm{C}_{3} \mathrm{~N}_{4}$ and O$\mathrm{C}_{3} \mathrm{~N}_{4}$

\begin{tabular}{|c|c|c|c|}
\hline \multicolumn{3}{|c|}{ XPS Analysis } & \multirow[b]{2}{*}{ Reference } \\
\hline Element & Kind of interaction & Binding energy, eV & \\
\hline \multirow[t]{7}{*}{$\mathbf{N}$} & \multicolumn{2}{|c|}{400} & $32,37,45-52,58,60$ \\
\hline & $\mathrm{N} 1\left(\mathrm{~N} \mathrm{sp}{ }^{2}\right) \mathrm{C}-\mathrm{N}=\mathrm{C}$ & 398.5 & $32,37,45,47-51,58$ \\
\hline & $\mathrm{N} 2(\mathrm{~N}-\mathrm{H})$ & 399.5 & $37,45,51$ \\
\hline & $\mathrm{N} 3\left(\mathrm{sp}^{3}\right) \mathrm{NC}_{3}$ & 400.2 & $32,37,45,47,49,50,58$ \\
\hline & $\mathrm{N} 4\left(\mathrm{NH}_{2}\right)$ & 401 & $32,45,48,49,58$ \\
\hline & $\begin{array}{c}\mathrm{N}-\mathrm{O} \text {, or due to } \mathrm{O}_{2} \text { and } \\
\mathrm{H}_{2} \mathrm{O} \text { adsorbed }\end{array}$ & 401.8 & 51 \\
\hline & $\mathrm{N} \pi-\pi$ & 404.2 & $37,45,50$ \\
\hline \multirow[t]{2}{*}{$\mathbf{C}$} & \multicolumn{2}{|c|}{284.8} & $32,37,45-52,58,60$ \\
\hline & $\mathrm{C}-\mathrm{C}$ & 284.6 & $32,37,45-47,49,58$ \\
\hline
\end{tabular}




\begin{tabular}{|c|c|c|c|}
\hline & $\mathrm{C}-\mathrm{CH}_{2}, \mathrm{C}-\mathrm{OH}, \mathrm{C}-\mathrm{O}$ & 286.2 & $37,45,46,48,58$ \\
\hline & $\mathrm{C}-\mathrm{N}$ & $287.2(286.2 \operatorname{ref} 8)$ & 32,45 \\
\hline & $\mathrm{C} 1$ & 288.2 & $37,45,47-49,58$ \\
\hline & $\mathrm{C} 2$ & 288.8 & 45 \\
\hline & $N-C=O$ & $289.8(288.9$ ref 8$)$ & $32,45,46,58$ \\
\hline & $\mathrm{C} \pi-\pi$ & 293.8 & 45 \\
\hline \multirow[t]{5}{*}{$\mathbf{O}$} & \multicolumn{2}{|c|}{532.6} & $32,37,45-48,58,60$ \\
\hline & $C=O$ & 530 & 61 \\
\hline & $\mathrm{C}-\mathrm{OH}, O-C-N$ & 531.9 & $32,36,46$ \\
\hline & $\mathrm{H}_{2} \mathrm{O}$ adsorbed & 532.9 & $37,46,48$ \\
\hline & $O-N$ & 533.4 & 32 \\
\hline
\end{tabular}

Theoretically, XPS should show a $\mathrm{C} / \mathrm{N}$ molar ratio of 0.75 for $\mathrm{g}-\mathrm{C}_{3} \mathrm{~N}_{4}$. Investigation of functional groups, particularly carbon oxygen functionalities, that could alter this ratio are detailed in Table 2. To understand the XPS signal, one must consider the differing bonding configurations that both nitrogen and carbon adopt in the $\mathrm{g}-\mathrm{C}_{3} \mathrm{~N}_{4}$ structure (Figure 10). Essentially, carbon has two unique bonding configurations $(\mathrm{C} 1, \mathrm{C} 2)$ whilst nitrogen adopts four unique configurations (from N1 to N4) in the carbon nitride structure. ${ }^{45}$ This causes a splitting in the XPS signal for each configuration allowing investigation of structure.

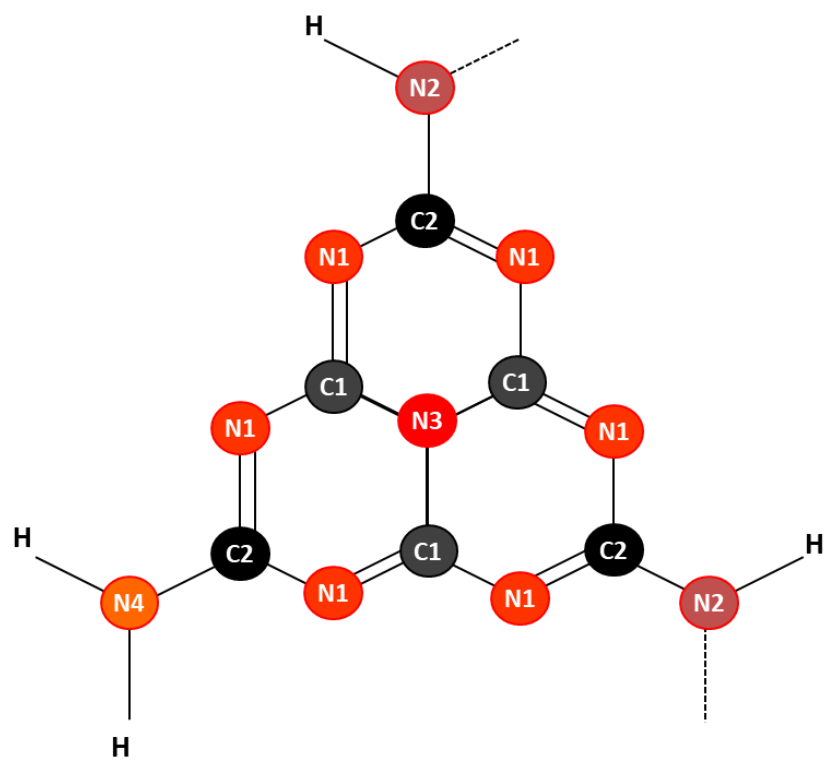

Figure 10. Structure of the repeating heptazine carbon nitride unit with the corresponding atomic assignment according to XPS analysis. 
Both elements $\mathrm{C}$ and $\mathrm{N}$, in the $\mathrm{C}_{3} \mathrm{~N}_{4}$ graphitic structure, generate the signal due to the $\pi$ to $\pi^{*}$ transition (shake-up) at around $293.8 \mathrm{eV}$ and $404.2 \mathrm{eV}$ respectively, as reported in Table 2 . In addition to chemical shifts in XPS due to different bonding configurations of carbon and nitrogen in perfect $\mathrm{C}_{3} \mathrm{~N}_{4}$ crystals, the peak positions due to oxygen functionalities characteristic of $\mathrm{O}-\mathrm{C}_{3} \mathrm{~N}_{4}$ samples are also reported in italic characters in Table 2.

Analysis of elemental composition via XPS was initiated with a wide energy survey (see Figure S3), performed in three locations, to look for contamination and estimate differences in the elemental constitution. Only carbon, nitrogen and oxygen peaks of significant magnitude for quantification were observed. The value of binding energy for each element observed showed good agreement with literature (see Table 2).

This analysis showed that the quantity of oxygen present in the pure as prepared $\mathrm{C}_{3} \mathrm{~N}_{4}$ is the lowest of all the samples. However, for samples that had undergone thermal annealing and/or testing as a photocatalyst, the oxygen content was increased in comparison to untreated material.

Table 3. Survey analysis average of three (wt\%) XPS measurements of used g- $\mathrm{C}_{3} \mathrm{~N}_{4}$, unused $\mathrm{g}-\mathrm{C}_{3} \mathrm{~N}_{4}$ and $\mathrm{O}_{\mathrm{R}}-\mathrm{C}_{3} \mathrm{~N}_{4}$ reference.

\begin{tabular}{|c|c|c|c|c|c|}
\cline { 2 - 6 } \multicolumn{1}{c|}{} & $\mathbf{O}_{\mathrm{R}}-\mathbf{C}_{\mathbf{3}} \mathbf{N}_{\mathbf{4}}$ & g- $\mathbf{C}_{\mathbf{3}} \mathbf{N}_{\mathbf{4}}$ & g- $\mathbf{C}_{\mathbf{3}} \mathbf{N}_{\mathbf{4}}$ used & $\mathbf{O}_{\mathbf{T}}-\mathbf{C}_{\mathbf{3}} \mathbf{N}_{\mathbf{4}}$ & $\mathbf{O}_{\mathbf{T}}-\mathbf{C}_{\mathbf{3}} \mathbf{N}_{\mathbf{4}}$ used \\
\hline $\mathrm{O}$ & 5.4 & 2.0 & 3.0 & 2.9 & 3.6 \\
\hline $\mathrm{C}$ & 49.6 & 48.6 & 49.9 & 48.5 & 48.0 \\
\hline $\mathrm{N}$ & 44.9 & 49.4 & 46.8 & 48.6 & 48.4 \\
\hline
\end{tabular}

By comparing changes in carbon and nitrogen percentages across sample groups, oxygen inclusion during synthesis of $\mathrm{O}_{\mathrm{R}}-\mathrm{C}_{3} \mathrm{~N}_{4}$, thermal treated $\mathrm{O}_{T}-\mathrm{C}_{3} \mathrm{~N}_{4}$ or used $\mathrm{g}-\mathrm{C}_{3} \mathrm{~N}_{4}$ data suggests that oxygen incorporated in the structure is likely substituting in one or more of the differing nitrogen positions $\mathrm{N} 1, \mathrm{~N} 2$ and N3. In fact, a loss in nitrogen concurrent with increases in oxygen percentage can be observed in Table 3. To discriminate between contributions from strongly adsorbed contaminants and 
different functional groups, high resolution scans of $\mathrm{N}, \mathrm{C}$ and $\mathrm{O}$ regions were measured (see figure S4) and deconvoluted based on assignments reported in Table 2.

For all samples analyzed, used and unused, a large proportion of the oxygen signal observed came from the water strongly bound to the catalyst. In the as prepared $g-\mathrm{C}_{3} \mathrm{~N}_{4}$ sample, all the oxygen observed was from adsorbed contaminants, $\mathrm{H}_{2} \mathrm{O}$ and $\mathrm{CO}_{2}$. Analysis of the $\mathrm{g}-\mathrm{C}_{3} \mathrm{~N}_{4}$ sample, thermally and chemically doped samples showed increased contributions from oxygen in lattice (N-C-O-C) and oxygen functionalization of periphery aromatic regions $(\mathrm{ArC}=\mathrm{O})$, as detailed in Table 4 .

Table 4. Contributions from different oxygen carbon and nitrogen functionalites (Wt \%) estimated from deconvolution of XPS each peak centred about at 288.4, 531.5 and $398.9 \mathrm{eV}$, respectively.

\begin{tabular}{|c|c|c|c|c|c|c|}
\hline & & \multicolumn{5}{|c|}{ Wt \% } \\
\hline & & $\mathrm{O}_{\mathrm{R}}-\mathrm{C}_{3} \mathrm{~N}_{4}$ & $\mathrm{~g}-\mathrm{C}_{3} \mathrm{~N}_{4}$ & $\begin{array}{c}\text { g- } \mathrm{C}_{3} \mathrm{~N}_{4} \\
\text { used }\end{array}$ & $\mathrm{O}_{\mathrm{T}}-\mathrm{C}_{3} \mathrm{~N}_{4}$ & $\mathrm{O}_{\mathrm{T}}-\mathrm{C}_{3} \mathrm{~N}_{4}$ used \\
\hline Binding energy, eV & O Type & \multicolumn{5}{|c|}{ Oxygen } \\
\hline 529.92 & $\mathrm{O}=\mathrm{CAr}$ & 1.37 & 0.00 & 0.00 & 1.35 & 2.38 \\
\hline 531.15 & $\mathrm{O}-\mathrm{C}-\mathrm{N}$ in lattice & 8.63 & 0.03 & 2.34 & 1.57 & 2.59 \\
\hline 532.28 & $\begin{array}{c}\mathrm{OH} \text { water, } \\
\mathrm{CO}_{2}\end{array}$ & 90.00 & 99.97 & 97.66 & 97.18 & 95.03 \\
\hline Binding energy, eV & N Type & \multicolumn{5}{|c|}{ Nitrogen } \\
\hline 398.72 & N1 edge & 68.23 & 71.34 & 64.47 & 65.28 & 66.88 \\
\hline 398.83 & N2 external & 8.43 & 3.77 & 6.83 & 10.29 & 7.50 \\
\hline 400.08 & N3 & 8.47 & 9.10 & 11.12 & 8.57 & 10.76 \\
\hline 401.08 & N4 external & 12.79 & 12.97 & 14.58 & 12.90 & 11.92 \\
\hline 404.25 & $\pi-\pi$ & 2.09 & 2.82 & 3.01 & 2.96 & 2.97 \\
\hline Binding energy, eV & C Type & \multicolumn{5}{|c|}{ Carbon } \\
\hline 284.82 & $\mathrm{C}-\mathrm{C}$ & 27.49 & 22.57 & 27.58 & 25.29 & 25.75 \\
\hline 286.4 & $\mathrm{C}-\mathrm{OH}$ & 5.43 & 3.30 & 3.74 & 1.81 & 1.83 \\
\hline 288 & $\mathrm{C} 1$ & 40.82 & 40.75 & 29.11 & 46.63 & 35.66 \\
\hline 288.6 & $\mathrm{C} 2$ & 22.28 & 28.76 & 33.81 & 21.33 & 30.92 \\
\hline 289.64 & $\mathrm{C}=\mathrm{O}$ external & 1.27 & 1.74 & 2.06 & 1.00 & 1.94 \\
\hline 293.37 & $\pi-\pi$ & 2.72 & 3.37 & 3.71 & 3.96 & 3.91 \\
\hline
\end{tabular}


This is suggestive that $\mathrm{UV}$-Vis irradiation of $\mathrm{g}-\mathrm{C}_{3} \mathrm{~N}_{4}$ in the presence of water leads to photocorrosion and oxidation of the $\mathrm{g}-\mathrm{C}_{3} \mathrm{~N}_{4}$. To understand the changes in the carbon nitride structure, due to increasing oxygenation, the nitrogen and carbon regions were also investigated. In the nitrogen region, due to the bonding in the $\mathrm{C}_{6} \mathrm{~N}_{10} \mathrm{H}_{12}$ heptazine monomer, nitrogen adopts four bonding configurations labelled N1 to N4 in Figure 10, each with a unique binding energy detailed as reported in literature in Table 2 and experimental data found in Table 4. N1 are present on the edges of heptazine base units, N3 are present at the center of a perfect heptazine base, whilst N2 type link heptazine sub units together and N4 represent the groups left upon the termination of polymerization. In a heptazine monomer (Figure 11a) the ratio of N1:N3:N4 is 6:1:3, N2 does not appear in the base unit melem; however as the monomer polymerizes, some $\mathrm{N} 4$ type are converted into $\mathrm{N} 2$ with the ratio of N4:N2 groups dependent on the geometry of polymerization (Figure 11c). In the g-h heptazine phase under study here, confirmed by XRD and UV-Vis (see above), heptazine monomers polymerize along parallel zig zag chains linked by single N4 units as illustrated in Figure 11e. Polymerizing in the g-h heptazine structure results in changes in the ratio of $\mathrm{N} 2$ to $\mathrm{N} 4$ nitrogen, relative to the monomer, as one N4 is replaced with one $\mathrm{N} 2$ for every unit extension along the polymerization axis. Illustration of the changes in nitrogen group bonding during polymerization is detailed in Figure 11. 


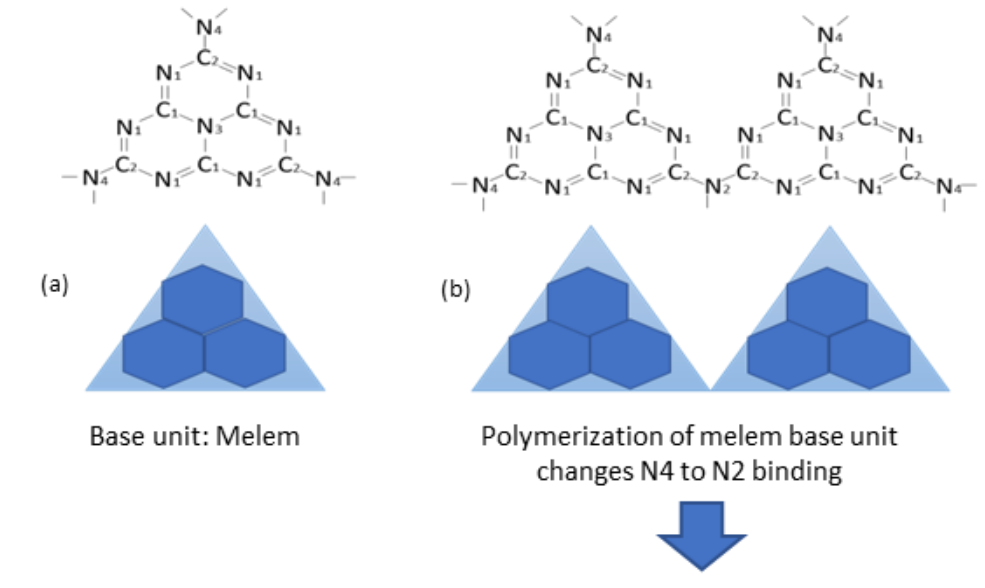

Geometry of base unit polymerization determines crystal phase

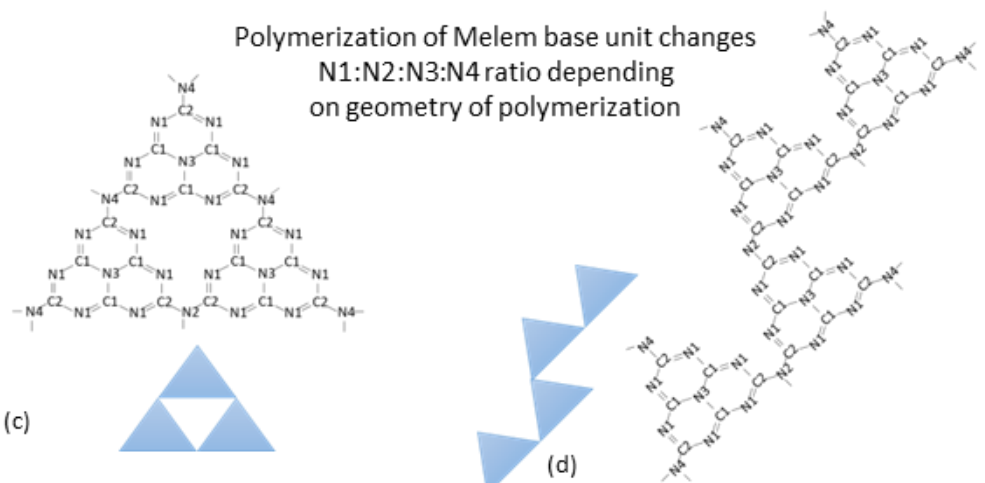

(d)

(e)

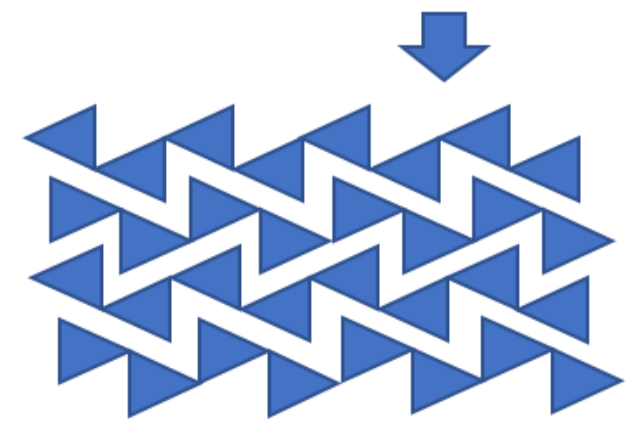

Figure 11. Pathway from Melem unit (a) and dimer (b) to polymeric $\mathrm{g}-\mathrm{C}_{3} \mathrm{~N}_{4}$ in two different geometry base unit, sheet (c) and firstly linear chain (d) and then in zig zag conformation (e).

Table 5. Change in nitrogen ratios as a function of chain length for h-g-heptazine structure.

\begin{tabular}{|c|c|c|c|c|c|c|c|c|}
\hline & N1 & N2 & N3 & N4 & N1 \% & N2 \% & N3 \% & N4 \% \\
\hline Dimer & 12 & 1 & 2 & 4 & 63.16 & 5.26 & 10.52 & 21.05 \\
\hline Tetramer & 12 & 1 & 2 & 3 & 66.66 & 5.55 & 11.11 & 16.67 \\
\hline Octamer & 12 & 1 & 2 & 2.5 & 68.85 & 5.71 & 11.43 & 14.28 \\
\hline Infinite chain & 12 & 1 & 2 & 2 & 70.58 & 5.88 & 11.76 & 11.76 \\
\hline
\end{tabular}


As reported in Table 5, the short heptazine chains result in $\mathrm{N} 1>\mathrm{N} 4>\mathrm{N} 3>\mathrm{N} 2$ ratio, whereas at the infinite chain lengths ratios become $\mathrm{N} 1>\mathrm{N} 4=\mathrm{N} 3>\mathrm{N} 2$ which is equivalent to a $\mathrm{N} 1: \mathrm{N} 2: \mathrm{N} 3: \mathrm{N} 4$ ratio of 12:1:2:2. This corresponds to $70.58: 5.88: 11.76: 11.76$ percentage ratio useful when comparing this perfect crystal to the percentages obtained from XPS.

For the synthesized $\mathrm{g}-\mathrm{C}_{3} \mathrm{~N}_{4}$, the N1:N2:N3:N4 percentage ratio from XPS was 71.34:3.77:9.10:12.97, which is good match for expected N1 \% in g-h-heptazine with largely perfect heptazine base units. Considering N4 suggests long range but not infinite chains consistent with XRD, the excess of N4 percentage may also be due to unreacted precursor / monomer material or some shorter chains. Deviation, a lower \% than expected, in N2 suggests crystal imperfections, defects or branching of the chains removing side N2 groups, whilst contemporaneously increasing N4 groups. Likewise, the N3 ratio was lower than expected for perfect crystals, suggesting vacancies in some of the heptazine blocks.

$\mathrm{N} 1: \mathrm{N} 2: \mathrm{N} 3: \mathrm{N} 4$ ratio from carbon nitride oxidized during synthesis, thermally or during photocatalysis are compared in Table 4. All treatments were observed to result in significant reduction in N1 side groups, relative to the starting material, suggestive of damage/distortion to the base of the heptazine unit. Deconvolution of the N2 and N4 (edge and terminal groups) in used $\mathrm{g}-\mathrm{C}_{3} \mathrm{~N}_{4}$ shows an increasing $\mathrm{N} 4$ percentages, suggesting a reduction in average chain length. In the $\mathrm{O}_{\mathrm{T}}-\mathrm{C}_{3} \mathrm{~N}_{4}$ sample, higher $\mathrm{N} 2$ and N4, with lower N1 ratios than expected for a perfect g-h-heptazine structure were observed, presumably due to oxygen disrupting periodicity. Its use as a potential photocatalyst showed further changes in the N1:N2:N3:N4, ratio which is consistent with additional restructuring of the polymer towards a more open arrangement.

Deconvolution of XPS C1s region was also used to look at changes in structure following photocatalysis. In this region, the $\mathrm{C}-\mathrm{C}$ and $\mathrm{C}-\mathrm{OH}$ peaks are characteristic of adsorbed species or deviance from heptazine structuring / reformation. Both thermal oxidation and use as a potential photocatalyst increased the $\mathrm{C}-\mathrm{C}$ peak indicative of a material with less heptazine/g- $\mathrm{C}_{3} \mathrm{~N}_{4}$ present. 
Likewise, signals due to $\mathrm{C}=\mathrm{O}$ bonding were observed to increase in both sample sets following use as photocatalysts, which is consistent with increasing counts in the oxygen region observed for the same treatment. $\mathrm{C} 1$ and $\mathrm{C} 2$ regions represent differing carbon nitrogen bonding. In all cases, it showed decreasing $\mathrm{C} 1$ and increasing $\mathrm{C} 2$ content following photocatalytic use due to changes in nitrogen content during use.

Intentional oxygen doping and repeated use in $\mathrm{CO}_{2}$ photocatalytic reduction experiments both led to reduced yields of $\mathrm{CO}$ in subsequent tests and simultaneous increases in the oxygen content of the g$\mathrm{C}_{3} \mathrm{~N}_{4}$. Also, UV-Vis irradiation was observed to give rise to changes in the $\mathrm{g}_{-} \mathrm{C}_{3} \mathrm{~N}_{4}$ structure (N1:N2:N3:N4 ratios).

Another factor to be considered is the role of $\mathrm{N}$ in the structure. In particular, as it can be noticed in Table 3 (XPS survey analysis), the increase of $\mathrm{O}$ content from the unused to used $\mathrm{g}-\mathrm{C}_{3} \mathrm{~N}_{4}$ sample and to $\mathrm{O}$ doped samples $\left(\mathrm{O}_{\mathrm{T}}-\mathrm{C}_{3} \mathrm{~N}_{4}\right.$ to $\left.\mathrm{O}_{\mathrm{R}} \mathrm{C}_{3} \mathrm{~N}_{4}\right)$ corresponds to a decrease of the total content of $\mathrm{N}$. This $\%$ variation which could be due to a replacement of $\mathrm{N}$ with $\mathrm{O}$ in the structure, could alter $\mathrm{CO}_{2}$ adsorption properties adversely.

In photocatalytic tests carried out in the presence of $\mathrm{CO}_{2}$ under the experimental conditions used (pressure, temperature, and light intensity), the increase in the $\mathrm{O}$ content of the $\mathrm{g}-\mathrm{C}_{3} \mathrm{~N}_{4}$ was caused by photocorrosion. It is not easy to determine if $\mathrm{H}_{2} \mathrm{O}, \mathrm{CO}_{2}$ or both are the source(s) of $\mathrm{O}$ observed in this work. The photocorrosion means the modification of the $\mathrm{C}_{3} \mathrm{~N}_{4}$ structure, due to the substitution of $\mathrm{N}$ with $\mathrm{O}$ during the photoreaction, as indicated by XPS measurements (see Table 3) and reported also by Huang et al when $\mathrm{H}_{2} \mathrm{O}_{2}$ was used to dope $\mathrm{C}_{3} \mathrm{~N}_{4}$ with oxygen. ${ }^{46}$ The mechanism which led to the final modified $\mathrm{C}_{3} \mathrm{~N}_{4}$ in our experimental conditions could give rise to formation of a nonstoichiometric or defective solid. Moreover, the figures related to the percentage of the various $\mathrm{N}$ types and shown in Table 3 strongly suggest a rearrangement of the g- $\mathrm{C}_{3} \mathrm{~N}_{4}$ structure following use in photocatalytic testing. 


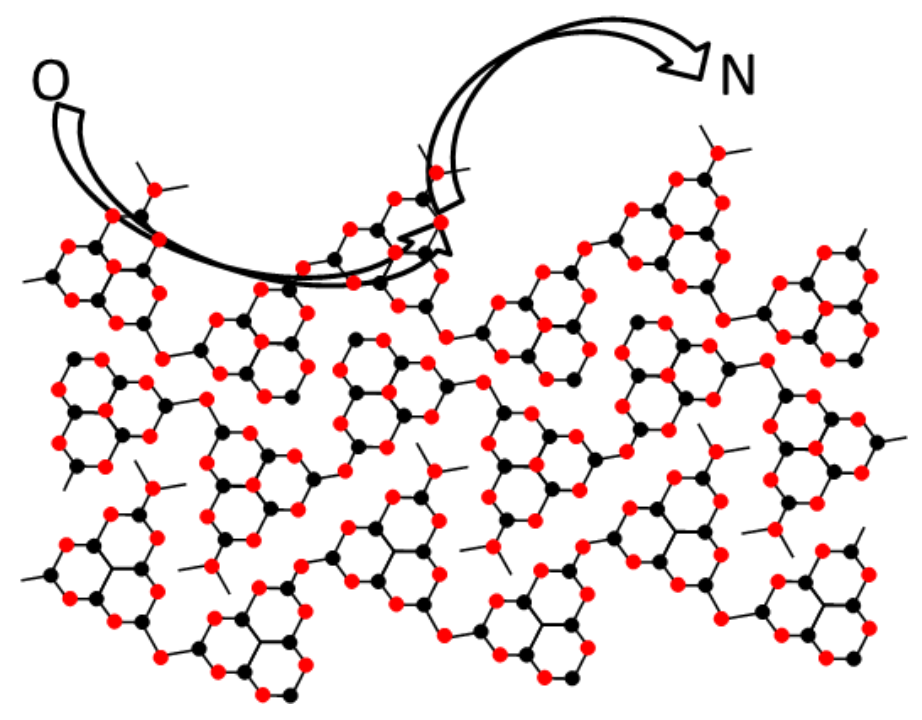

Figure 12. Schematic illustration of $\mathrm{N}$ replacement by $\mathrm{O}$ in $\mathrm{g}-\mathrm{C}_{3} \mathrm{~N}_{4}$ material, where red and black dots indicate $\mathrm{N}$ and $\mathrm{C}$ element, respectively, replacing with $\mathrm{O}$.

As far as the runs carried out in the absence of $\mathrm{CO}_{2}$ are concerned, the presence of $\mathrm{CO}_{2}$ adsorbed on the catalyst surface or as impurity in the system cannot be excluded and it can be compatible with the CO formation. ${ }^{44}$

In current literature, only a few papers report repeat testing and generally they concern runs carried out using $\mathrm{C}_{3} \mathrm{~N}_{4}$ composites and or bulk materials with low surface area. Qin et al, ${ }^{40}$ observed that in the presence of barbituric acid-g- $\mathrm{C}_{3} \mathrm{~N}_{4}$ composite the photoreduction of $\mathrm{CO}_{2}$ to $\mathrm{CO}$ and $\mathrm{H}_{2}$ was quite reproducible, at least after three catalytic consecutive tests. Probably, in this case, the presence of barbituric acid stabilized the $\mathrm{g}-\mathrm{C}_{3} \mathrm{~N}_{4}$ structure avoiding the replacement of $\mathrm{N}$ by $\mathrm{O}$ and consequently no decreasing activity was observed. A similar stabilizing effect due to the presence of ceria can be hypothesized in the case of $\mathrm{CeO}_{2}-\mathrm{C}_{3} \mathrm{~N}_{4}$ composite that showed a constant $\mathrm{CH}_{4}$ and $\mathrm{CO}$ production after 4 runs as reported from $\mathrm{Li}$ et al. ${ }^{29}$

In contrast with the present study, $\mathrm{Fu}$ et al. reported reproducible photoreduction of $\mathrm{CO}_{2}$ with both bulk $\mathrm{g}-\mathrm{C}_{3} \mathrm{~N}_{4}$ and $\mathrm{O}-\mathrm{C}_{3} \mathrm{~N}_{4}$ photocatalysts. However, it is important to note that the amount of $\mathrm{CO}_{2}$ photoreduction products observed by Fu et al. was always lower than the lowest one revealed in our study. Moreover, no structural studies were carried out on the $\mathrm{g}-\mathrm{C}_{3} \mathrm{~N}_{4}$ photocatalyst following use for 
$\mathrm{CO}_{2}$ reduction. ${ }^{32}$ Interestingly, in that work no $\mathrm{CO}$ formation was observed during control experiments in the absence of $\mathrm{CO}_{2}$.

\section{Conclusions}

During testing of $\mathrm{g}-\mathrm{C}_{3} \mathrm{~N}_{4}$ and oxygen doped $\mathrm{g}-\mathrm{C}_{3} \mathrm{~N}_{4}$ as the photocatalysts for $\mathrm{CO}_{2}$ reduction, the main product detected was $\mathrm{CO}$. No other products were detected. The pure material was observed to be more active than the oxygen modified analogue for $\mathrm{CO}$ production. A reduction in the rate of $\mathrm{CO}$ generation, under irradiation, was observed during both single runs and repeated test cycles with the same catalyst. During control tests in the absence of $\mathrm{CO}_{2}$, the production of $\mathrm{CO}$ was observed under irradiation, raising questions about the origin of the $\mathrm{CO}$ and the stability of $\mathrm{g}-\mathrm{C}_{3} \mathrm{~N}_{4}$.

Diffuse reflectance FT-IR analysis showed the expected functional groups characteristic of $\mathrm{g}-\mathrm{C}_{3} \mathrm{~N}_{4}$ present in all samples. Functional group peak intensity declined with oxygen doping or photocatalytic use. Given the qualitative nature of FTIR, samples were further investigated with XPS to quantify the changes in the functional groups during photocatalytic use or intentional oxidation.

FTIR and XPS analysis showed that the thermal and the photocatalytic treatments produce similar changes to the functional groups, consistent with oxidation of the $\mathrm{C}_{3} \mathrm{~N}_{4}$ structure. The oxidation of the $\mathrm{g}-\mathrm{C}_{3} \mathrm{~N}_{4}$ under UV-Vis irradiation was slightly different to the one obtained with oxygen doping, but produced the same effect on catalytic behavior, i.e. a reduction in product yield under irradiation.

The XPS data showed an increase in oxygen content, both absolute and bound to carbon, after thermal treatment and after photocatalytic use. This study allowed the examination of where and how oxidation disrupts the material structure, showing changes to the heptazine base units along with changes in bonding between units following oxidation or photocatalytic use. 
This work points that under our reactor conditions, the photoexcitation actually leads to oxidation of $\mathrm{C}_{3} \mathrm{~N}_{4}$ rather than water splitting, leading to a loss of photocatalytic activity i.e. photocorrosion. Given that the valence band edge of $\mathrm{g}-\mathrm{C}_{3} \mathrm{~N}_{4}$ is close to the water oxidation potential, this material has limited over-potential to drive water oxidation and as such, may accumulate intermediate ROS species that may oxidize the catalyst, changing its activity as observed here. $\mathrm{C}_{3} \mathrm{~N}_{4}$ may still be useful as a photocatalyst; however, the use of a z-scheme or a second co-catalyst material on which to run the oxidation reaction may be necessary to avoid g- $\mathrm{C}_{3} \mathrm{~N}_{4}$ oxidation. Many researchers use a z-scheme consisting of $\mathrm{g}-\mathrm{C}_{3} \mathrm{~N}_{4}$ in composite materials such as $\mathrm{g}-\mathrm{C}_{3} \mathrm{~N}_{4}-\mathrm{TiO}_{2}$ where the latter material performs the water oxidations steps, decreasing the probability of $g-\mathrm{C}_{3} \mathrm{~N}_{4}$ oxidation.

\section{Supporting Information}

Measurement of irradiance from 100W Xe lamp with IR filter, representative XPS survey, C, N and O XPS analysis and the quantum yield of all samples are reported. This material is available free of charge via the Internet at ...

\section{Acknowledgements}

We wish to acknowledge funding from the US-Ireland R\&D Collaborative Partnership Program NSF (CBET-1438721), SFI (SFI 14/US/E2915) and DfE (USI065) and the financial support from British Council under the STREAM-MENA Institutional Links Scheme (Grant number 278072873). F.R. Pomilla also gratefully acknowledge the "SIACE" Ph.D. Course at the University of Calabria and the Institute for Membrane Technology - Council National Research (ITM-CNR) of Cosenza (Italy) for financial support. 


\section{References}

1. 2020 climate \& energy package. https://ec.europa.eu/clima/policies/strategies/2020_en (accessed 26-03-2018).

2. Finn, C.; Schnittger, S.; Yellowlees, L. J.; Love, J. B. Molecular Approaches to the Electrochemical Reduction of Carbon Dioxide. Chem. Commun. 2012, 48, 1392-1399.

3. Liang, Y.; Shang, R.; Lu, J.; Liu, L.; Hu, J.; Cui, W. Ag $\mathrm{AO}_{3} @$ @MOFNs Core-Shell Structure: Two-Dimensional MOFs Promoted Photoinduced Charge Separation and Photocatalysis. ACS Appl. Mater. Interfaces 2018, 10, 8758-8769.

4. $\quad$ Chen, F.; An, W.; Liu, L.; Liang, Y.; Cui, W. Highly Efficient Removal of Bisphenol A by a Three-Dimensional Graphene Hydrogel-AgBr@rGO Exhibiting Adsorption/Photocatalysis Synergy. Appl. Catal., B 2017, 217, 65-80.

5. $\quad$ Ronge, J.; Bosserez, T.; Martel, D.; Nervi, C.; Boarino, L.; Taulelle, F.; Decher, G.; Bordiga, S.; Martens, J. A. Monolithic Cells for Solar Fuels. Chem. Soc. Rev. 2014, 43, 7963-7981.

6. Bosserez, T.; Rongé, J.; van Humbeeck, J.; Haussener, S.; Martens, J. Design of Compact Photoelectrochemical Cells for Water Splitting. Oil Gas Sci. Technol. 2015, 70, 877-889.

7. Hankin, A.; Bedoya-Lora, F. E.; Ong, C. K.; Alexander, J. C.; Petter, F.; Kelsall, G. H. From Millimetres to Metres: the Critical Role of Current Density Distributions in Photo-Electrochemical Reactor Design. Energy Environ. Sci. 2017, 10, 346-360.

8. Cui, W.; He, J.; Wang, H.; Hu, J.; Liu, L.; Liang, Y. Polyaniline Hybridization Promotes Photo-Electro-Catalytic Removal of Organic Contaminants over 3D Network Structure of rGH$\mathrm{PANI} / \mathrm{TiO}_{2}$ hydrogel. Applied Catalysis B: Environmental 2018, 232, 232-245.

9. Zhang, Y.; Cui, W.; An, W.; Liu, L.; Liang, Y.; Zhu, Y. Combination of Photoelectrocatalysis and Adsorption for Removal of Bisphenol A over $\mathrm{TiO}_{2}$-Graphene Hydrogel with 3D Network Structure. Appl. Catal. B: 2018, 221, 36-46.

10. Jiang, L.; Yuan, X.; Zeng, G.; Wu, Z.; Liang, J.; Chen, X.; Leng, L.; Wang, H.; Wang, H. Metal-free Efficient Photocatalyst for Stable Visible-light Photocatalytic Degradation of Refractory Pollutant. Appl. Catal. B: 2018, 221, 715-725.

11. Ong, W.-J.; Tan, L. L.; Ng, Y. H.; Yong, S.T.; Chai, S. P. Graphitic Carbon Nitride (g-C $\left.3 \mathrm{~N}_{4}\right)-$ Based Photocatalysts for Artificial Photosynthesis and Environmental Remediation: Are We a Step Closer To Achieving Sustainability? Chem. Rev. 2016, 116, 7159-7329.

12. Wang, X.; Liang, Y.; An, W.; Hu, J.; Zhu, Y.; Cui, W. Removal of Chromium (VI) by a SelfRegenerating and Metal Free g- $\mathrm{C}_{3} \mathrm{~N}_{4} /$ Graphene Hydrogel System Via the Synergy of Adsorption and Photo-Catalysis Under Visible Light. Appl. Catal. B: 2017, 219, 53-62.

13. Ye, S.; Wang, R.; Wu, M.-Z.; Yuan, Y. P. A Review on $\mathrm{g}_{-} \mathrm{C}_{3} \mathrm{~N}_{4}$ for Photocatalytic Water Splitting and $\mathrm{CO}_{2}$ Reduction. Appl.Surf. Sci. 2015, 358, 15-27.

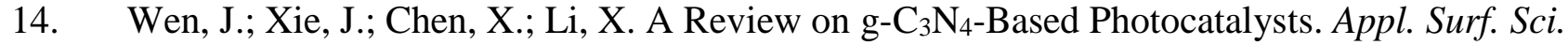
2017, 391, 72-123.

15. Meng, J.; Pei, J.; He, Z.; Wu, S.; Lin, Q.; Wei, X.; Li, J.; Zhang, Z. Facile Synthesis of g-C ${ }_{3} \mathrm{~N}_{4}$ Nanosheets Loaded with $\mathrm{WO}_{3}$ Nanoparticles with Enhanced Photocatalytic Performance Under Visible Light Irradiation. RSC Adv. 2017, 7, 24097-24104.

16. Murugesan, P.; Narayanan, S.; Manickam, M. Experimental Studies on Photocatalytic Reduction of $\mathrm{CO}_{2}$ using $\mathrm{AgBr}$ Decorated $\mathrm{g}-\mathrm{C}_{3} \mathrm{~N}_{4}$ Composite in TEA Mediated System. J. CO Util. 2017, 22, 250-261.

17. Li, H.; Gao, Y.; Xiong, Z.; Liao, C.; Shih, K. Enhanced Selective Photocatalytic Reduction of $\mathrm{CO}_{2}$ to $\mathrm{CH}_{4}$ over Plasmonic Au Modified g- $\mathrm{C}_{3} \mathrm{~N}_{4}$ Photocatalyst Under UV-vis Light Irradiation. Appl. Surf. Sci. 2018, 439, 552-559.

18. Liu, S.; Chen, F.; Li, S.; Peng, X.; Xiong, Y. Enhanced Photocatalytic Conversion of Greenhouse Gas $\mathrm{CO}_{2}$ into Solar Fuels over g- $\mathrm{C}_{3} \mathrm{~N}_{4}$ Nanotubes with Decorated Transparent ZIF-8 Nanoclusters. Appl. Catal. B: 2017, 211, 1-10. 
19. Liu, H.; Zhang, Z.; Meng, J.; Zhang, J. Novel Visible-Light-Driven $\mathrm{CdIn}_{2} \mathrm{~S}_{4} /$ Mesoporous g$\mathrm{C}_{3} \mathrm{~N}_{4}$ Hybrids for Efficient Photocatalytic Reduction of $\mathrm{CO}_{2}$ to Methanol. Mol. Catal. 2017, 430, 919.

20. Raziq, F.; Qu, Y.; Humayun, M.; Zada, A.; Yu, H.; Jing, L. Synthesis of $\mathrm{SnO}_{2} / \mathrm{B}-\mathrm{P}$ Codoped g- $\mathrm{C}_{3} \mathrm{~N}_{4}$ Nanocomposites as Efficient Cocatalyst-free Visible-Light Photocatalysts for $\mathrm{CO}_{2}$ Conversion and Pollutant Degradation. Applied Catalysis B: Environmental 2017, 201, 486-494.

21. Kamat, P. V. Manipulation of Charge Transfer Across Semiconductor Interface. A Criterion That Cannot Be Ignored in Photocatalyst Design. J. Phys. Chem. Lett. 2012, 3 (5), 663-672.

22. Guijarro, N.; Prevot, M. S.; Sivula, K. Surface Modification of Semiconductor Photoelectrodes. Phys. Chem. Chem. Phys. 2015, 17, 15655-15674.

23. Mu, C.; Zhang, Y.; Cui, W.; Liang, Y.; Zhu, Y. Removal of Bisphenol A over a Separation Free 3D $\mathrm{Ag}_{3} \mathrm{PO}_{4}-\mathrm{Graphene}$ Hydrogel via an Adsorption-Photocatalysis Synergy. Appl. Catal. B: 2017, 212, 41-49.

24. Bai, S.; Wang, X.; Hu, C.; Xie, M.; Jiang, J.; Xiong, Y. Two-Dimensional g-C ${ }_{3} \mathrm{~N}_{4}$ : an Ideal Platform for Examining Facet Selectivity of Metal co-catalysts in Photocatalysis. Chem. Commun. 2014, 50 (46), 6094-6097.

25. Lin, J.; Pan, Z.; Wang, X. Photochemical Reduction of $\mathrm{CO}_{2}$ by Graphitic Carbon Nitride Polymers. ACS Sustain. Chem. \& Eng. 2014, 2, 353-358.

26. Kuriki, R.; Sekizawa, K.; Ishitani, O.; Maeda, K. Visible-Light-Driven $\mathrm{CO}_{2}$ Reduction with Carbon Nitride: Enhancing the Activity of Ruthenium Catalysts. Angew. Chem. Int. Ed. 2015, 54, 2406-2409.

27. Ong, W. J.; Tan, L. L.; Chai, S. P.; Yong, S. T. Heterojunction Engineering of Graphitic Carbon Nitride $\left(\mathrm{g}-\mathrm{C}_{3} \mathrm{~N}_{4}\right)$ via Pt Loading With Improved Daylight-Induced Photocatalytic Reduction of Carbon Dioxide to Methane. Dalton Trans. 2015, 44, 1249-1257.

28. Ohno, T.; Murakami, N.; Koyanagi, T.; Yang, Y. Photocatalytic Reduction of $\mathrm{CO}_{2}$ over a Hybrid Photocatalyst Composed of $\mathrm{WO}_{3}$ and Graphitic Carbon Nitride $\left(\mathrm{g}-\mathrm{C}_{3} \mathrm{~N}_{4}\right)$ Under Visible Light. J. $\mathrm{CO}_{2}$ Util. 2014, 6, 17-25.

29. Li, M.; Zhang, L.; Wu, M.; Du, Y.; Fan, X.; Wang, M.; Zhang, L.; Kong, Q.; Shi, J. Mesostructured $\mathrm{CeO}_{2} / \mathrm{g}-\mathrm{C}_{3} \mathrm{~N}_{4}$ nanocomposites: Remarkably Enhanced Photocatalytic Activity for CO2 Reduction by Mutual Component Activations. Nano Energy 2016, 19, 145-155.

30. Zhou, S.; Liu, Y.; Li, J.; Wang, Y.; Jiang, G.; Zhao, Z.; Wang, D.; Duan, A.; Liu, J.; Wei, Y. Facile in Situ Synthesis of Graphitic Carbon Nitride $\left(\mathrm{g}-\mathrm{C}_{3} \mathrm{~N}_{4}\right)-\mathrm{N}-\mathrm{TiO}_{2}$ Heterojunction as an Efficient Photocatalyst for the Selective Photoreduction of $\mathrm{CO}_{2}$ to CO. Appl. Cat. B: 2014, 158-159, $20-29$.

31. Wang, K.; Li, Q.; Liu, B.; Cheng, B.; Ho, W.; Yu, J. Sulfur-Doped g-C ${ }_{3} \mathrm{~N}_{4}$ with Enhanced Photocatalytic $\mathrm{CO}_{2}$-Reduction Performance. Appl. Cat. B: 2015, 176, 44-52.

32. Fu, J.; Zhu, B.; Jiang, C.; Cheng, B.; You, W.; Yu, J. Hierarchical Porous O-Doped g-C3N4 with Enhanced Photocatalytic $\mathrm{CO}_{2}$ Reduction Activity. Small 2017, 13, 1603938-n/a.

33. Zhang, L.; Zhang, Y.; Shi, R.; Bao, S.; Wang, J.; Amini, A.; Chandrashekar, B. N.; Cheng, C. Phosphorous Doped Graphitic- $\mathrm{C}_{3} \mathrm{~N}_{4}$ Hierarchical Architecture for Hydrogen Production from Water Under Visible Light. Mater. Today Energy 2017, 5, 91-98.

34. Osorio-Guillén, J. M.; Espinosa-García, W. F.; Moyses Araujo, C. Assessing Photocatalytic Power of $\mathrm{g}_{-} \mathrm{C}_{3} \mathrm{~N}_{4}$ for Solar Fuel Production: A First-Principles Study Involving Quasi-Particle Theory and Dispersive Forces. J. Chem. Phy. 2015, 143, 094705.

35. $\mathrm{Xu}, \mathrm{Y}$; Gao, S. P. Band Gap of $\mathrm{C}_{3} \mathrm{~N}_{4}$ in the GW Approximation. Int. J. Hydrogen Energy 2012, 37 (15), 11072-11080.

36. Jiang, L.; Yuan, X.; Pan, Y.; Liang, J.; Zeng, G.; Wu, Z.; Wang, H. Doping of Graphitic Carbon Nitride for Photocatalysis: A Reveiw. Appl.Catal. B: 2017, 217, 388-406.

37. Mao, J.; Peng, T.; Zhang, X.; Li, K.; Ye, L.; Zan, L. Effect of Graphitic Carbon Nitride Microstructures on the Activity and Selectivity of Photocatalytic $\mathrm{CO}_{2}$ Reduction Under Visible Light. Catal. Sci. Techn. 2013, 3, 1253-1260. 
38. Dong, G.; Zhang, L., Porous structure dependent photoreactivity of graphitic carbon nitride under visible light. Journal of Materials Chemistry 2012, 22 (3), 1160-1166.

39. Liu, L.; Yue, M.; Lu, J.; Hu, J.; Liang, Y.; Cui, W. The Enrichment of Photo-Catalysis Via Self-Assembly Perylenetetracarboxylic Acid Diimide Polymer Nanostructures Incorporating $\mathrm{TiO}_{2}$ Nano-Particles. Appl. Surf. Sci. 2018, 456, 645-656.

40. Qin, J.; Wang, S.; Ren, H.; Hou, Y.; Wang, X. Photocatalytic Reduction of $\mathrm{CO}_{2}$ by Graphitic Carbon Nitride Polymers Derived from Urea and Barbituric Acid. Appl. Catal. B: 2015, 179, 1-8.

41. Xiao, J.; Han, Q.; Xie, Y.; Yang, J.; Su, Q.; Chen, Y.; Cao, H. Is $\mathrm{C}_{3} \mathrm{~N}_{4}$ Chemically Stable toward Reactive Oxygen Species in Sunlight-Driven Water Treatment? Environ. Sci. Techn. 2017, 51, 13380-13387.

42. Pomilla, F. R.; Brunetti, A.; Marci, G.; Garcia-Lopez, E. I.; Fontananova, E.; Palmisano, L.; Barbieri, G. $\mathrm{CO}_{2}$ to Liquid Fuels: Photocatalytic Conversion in a Continuous Membrane Reactor. ACS Sustainable Chem. Eng. 2018,6, 8743-8753.

43. Dong, G.; Ai, Z.; Zhang, L. Efficient Anoxic Pollutant Removal with Oxygen Functionalized Graphitic Carbon Nitride Under Visible Light. RSC Adv. 2014, 4, 5553-5560.

44. Cortes, M. A. L. R. M.; Hamilton, J. W. J.; Sharma, P. K.; Brown, A.; Nolan, M.; Gray, K. A.; Byrne, J. A. Formal Quantum Efficiencies for the Photocatalytic Reduction of $\mathrm{CO}_{2}$ in a Gas Phase Batch Reactor. Catal. Today 2018.

45. Dante, R. C.; Sánchez-Arévalo, F. M.; Chamorro-Posada, P.; Vázquez-Cabo, J.; Huerta, L.; Lartundo-Rojas, L.; Santoyo-Salazar, J.; Solorza-Feria, O.; Diaz-Barrios, A.; Zoltan, T.; Vargas, F.; Valenzuela, T.; Muñoz-Bisesti, F.; Quiroz-Chávez, F. J., Synthesis and characterization of Cu-doped polymeric carbon nitride. Fullerenes, Nanotubes and Carbon Nanostructures 2016, 24 (3), 171-180. 46. Huang, Z.-F.; Song, J.; Pan, L.; Wang, Z.; Zhang, X.; Zou, J.-J.; Mi, W.; Zhang, X.; Wang, L., Carbon nitride with simultaneous porous network and O-doping for efficient solar-energy-driven hydrogen evolution. Nano Energy 2015, 12 (Supplement C), 646-656.

47. Li, X.; Zhang, J.; Shen, L.; Ma, Y.; Lei, W.; Cui, Q.; Zou, G., Preparation and characterization of graphitic carbon nitride through pyrolysis of melamine. Applied Physics A 2009, 94 (2), 387-392. 48. Adekoya, D. O.; Tahir, M.; Amin, N. A. S., g- $\mathrm{C}_{3} \mathrm{~N}_{4} /\left(\mathrm{Cu} / \mathrm{TiO}_{2}\right)$ nanocomposite for enhanced photoreduction of $\mathrm{CO}_{2}$ to $\mathrm{CH}_{3} \mathrm{OH}$ and $\mathrm{HCOOH}$ under UV/visible light. Journal of $\mathrm{CO}_{2}$ Utilization 2017, 18 (Supplement C), 261-274.

49. Ren, J.; Chai, Y.; Liu, Q.; Zhang, L.; Dai, W.-L., Intercorrelated $\mathrm{Ag}_{3} \mathrm{PO}_{4}$ nanoparticles decorated with graphic carbon nitride: Enhanced stability and photocatalytic activities for water treatment. Applied Surface Science 2017, 403 (Supplement C), 177-186.

50. Zhou, Z.; Wang, J.; Yu, J.; Shen, Y.; Li, Y.; Liu, A.; Liu, S.; Zhang, Y., Dissolution and Liquid Crystals Phase of 2D Polymeric Carbon Nitride. Journal of the American Chemical Society 2015, 137 (6), 2179-2182.

51. Montigaud, H.; Tanguy, B.; Demazeau, G.; Alves, I.; Courjault, S. $\mathrm{C}_{3} \mathrm{~N}_{4}$ : Dream or Reality? Solvothermal Synthesis as Macroscopic Samples of the $\mathrm{C}_{3} \mathrm{~N}_{4}$ Graphitic Form. J. Mater. Sci. 2000, 35, 2547-2552.

52. Dante, R. C.; Martín-Ramos, P.; Correa-Guimaraes, A.; Martín-Gil, J. Synthesis of Graphitic Carbon Nitride by Reaction of Melamine and Uric Acid. Mater. Chem. Phys. 2011, 130, 1094-1102. 53. She, X.; Liu, L.; Ji, H.; Mo, Z.; Li, Y.; Huang, L.; Du, D.; Xu, H.; Li, H. Template-Free Synthesis of 2D Porous Ultrathin Nonmetal-Doped $\mathrm{g}_{-} \mathrm{C}_{3} \mathrm{~N}_{4}$ Nanosheets with Highly Efficient photocatalytic $\mathrm{H}_{2}$ evolution from water under visible light. Appl. Catal. B: 2016, 187, 144-153.

54. Fina, F.; Callear, S. K.; Carins, G. M.; Irvine, J. T. S. Structural Investigation of Graphitic Carbon Nitride via XRD and Neutron Diffraction. Chem. Mater.2015, 27, 2612-2618.

55. Zhang, H.; Zuo, X.; Tang, H.; Li, G.; Zhou, Z. Origin of Photoactivity in Graphitic Carbon Nitride and Strategies for Enhancement of Photocatalytic Efficiency: Insights from First-Principles Computations. Phys. Chem. Chem. Phys. 2015, 17, 6280-6288. 
56. Wu, H.-Z.; Bandaru, S.; Liu, J.; Li, L. L.; Wang, Z. Adsorption of $\mathrm{H}_{2} \mathrm{O}, \mathrm{H}_{2}, \mathrm{O}_{2}, \mathrm{CO}$, NO, and $\mathrm{CO}_{2}$ on Graphene/g- $\mathrm{C}_{3} \mathrm{~N}_{4}$ Nanocomposite Investigated by Density Functional Theory. Appl. Surf. Sci. 2018, 430, 125-136.

57. Tan, L. L.; Ong, W. J.; Chai, S. P.; Mohamed, A. R. Photocatalytic Reduction of $\mathrm{CO}_{2}$ with $\mathrm{H}_{2} \mathrm{O}$ over Graphene Oxide-Supported Oxygen-Rich $\mathrm{TiO}_{2}$ Hybrid Photocatalyst Under Visible Light Irradiation: Process and Kinetic Studies. Chem. Eng. J. 2017, 308, 248-255.

58. Oh, J.; Yoo, R. J.; Kim, S. Y.; Lee, Y. J.; Kim, D. W.; Park, S. Oxidized Carbon Nitrides: Water-Dispersible, Atomically Thin Carbon Nitride-Based Nanodots and Their Performances as Bioimaging Probes. Chem. Eur. J. 2015, 21, 6241-6246.

59. Bai, G.; Song, Z.; Geng, H.; Gao, D.; Liu, K.; Wu, S.; Rao, W.; Guo, L.; Wang, J. Oxidized Quasi-Carbon Nitride Quantum Dots Inhibit Ice Growth. Adv. Mater. 2017, 29, 1606843-n/a.

60. Wang, H.; Sun, Z.; Li, Q.; Tang, Q.; Wu, Z. Surprisingly Advanced $\mathrm{CO}_{2}$ Photocatalytic Conversion over Thiourea Derived $\mathrm{g}_{-} \mathrm{C}_{3} \mathrm{~N}_{4}$ with Water Vapor While Introducing 200-420nm UV light. J. $\mathrm{CO}_{2}$ Utiliz. 2016, 14, 143-151.

61. High Resolution XPS of Organic Polymers: The Scienta ESCA300 Database. Beamson, G.; Briggs, D. John Wiley \& Sons, Ltd, Chichester, 1992. 
Table of contents (TOC)

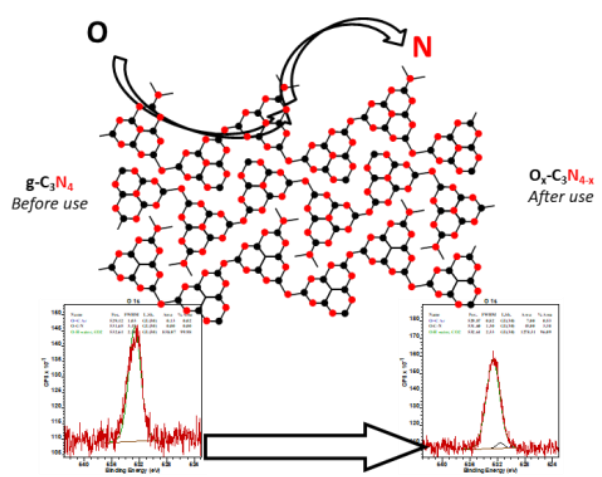

